\title{
Pasture degradation modifies the water and carbon cycles of the Tibetan highlands
}

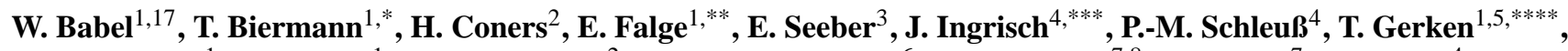 \\ J. Leonbacher ${ }^{1}$, T. Leipold ${ }^{1}$, S. Willinghöfer ${ }^{2}$, K. Schützenmeister ${ }^{6}$, O. Shibistova ${ }^{7,8}$, L. Becker ${ }^{7}$, S. Hafner $^{4}$,

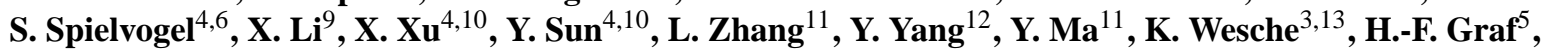 \\ C. Leuschner ${ }^{2}$, G. Guggenberger ${ }^{7}$, Y. Kuzyakov ${ }^{4,14,15}$, G. Miehe ${ }^{16}$, and T. Foken ${ }^{1,17}$ \\ ${ }^{1}$ University of Bayreuth, Department of Micrometeorology, Bayreuth, Germany \\ ${ }^{2}$ University of Göttingen, Department of Plant Ecology and Ecosystem Research, Göttingen, Germany \\ ${ }^{3}$ Senckenberg Museum Görlitz, Department of Botany, Görlitz, Germany \\ ${ }^{4}$ University of Göttingen, Department of Soil Sciences of Temperate Ecosystems, Göttingen, Germany \\ ${ }^{5}$ University of Cambridge, Department of Geography, Centre for Atmospheric Science, Cambridge, UK \\ ${ }^{6}$ University of Koblenz-Landau, Institute of Integrated Environmental Sciences, Koblenz, Germany \\ ${ }^{7}$ Leibniz Universität Hannover, Institute for Soil Science, Hanover, Germany \\ ${ }^{8}$ V. N. Sukachev Institute of Forest, Krasnoyarsk, Russia \\ ${ }^{9}$ School of Life Sciences, Lanzhou University, Lanzhou, China \\ ${ }^{10}$ Chinese Academy of Sciences, Institute of Geographical Sciences and Natural Resources Research, Beijing, China \\ ${ }^{11}$ Chinese Academy of Sciences, Institute of Tibetan Plateau Research, Key Laboratory of Tibetan Environment Changes and \\ Land Surface, Processes, Beijing, China \\ ${ }^{12}$ Chinese Academy of Sciences, Institute of Tibetan Plateau Research, Laboratory of Alpine Ecology and Biodiversity \\ Focuses, Processes, Beijing, China \\ ${ }^{13}$ German Centre for Integrative Biodiversity Research (iDiv) Halle-Jena-Leipzig, Germany \\ ${ }^{14}$ University of Göttingen, Department of Agricultural Soil Science, Göttingen, Germany \\ ${ }^{15}$ Institute of Environmental Sciences, Kazan Federal University, Kazan, Russia \\ ${ }^{16}$ University of Marburg, Faculty of Geography, Marburg, Germany \\ ${ }^{17}$ Member of Bayreuth Center of Ecology and Ecosystem Research, Bayreuth, Germany \\ *now at: Lund University, Centre for Environmental and Climate Research, Lund, Sweden \\ *** now at: Thünen Institute of Climate-Smart Agriculture, Braunschweig, Germany \\ ${ }^{* * * *}$ now at: University of Innsbruck Institute of Ecology Research, Innsbruck, Austria \\ ${ }^{* * * * *}$ now at: The Pennsylvania State University, Department of Meteorology, University Park, PA, USA
}

Correspondence to: T. Foken (thomas.foken@uni-bayreuth.de)

Received: 21 May 2014 - Published in Biogeosciences Discuss.: 12 June 2014

Revised: 29 October 2014 - Accepted: 30 October 2014 - Published: 2 December 2014

\begin{abstract}
The Tibetan Plateau has a significant role with regard to atmospheric circulation and the monsoon in particular. Changes between a closed plant cover and open bare soil are one of the striking effects of land use degradation observed with unsustainable range management or climate change, but experiments investigating changes of surface properties and processes together with atmospheric feedbacks are rare and have not been undertaken in the world's
\end{abstract}

two largest alpine ecosystems, the alpine steppe and the Kobresia pygmaea pastures of the Tibetan Plateau. We connected measurements of micro-lysimeter, chamber, ${ }^{13} \mathrm{C}$ labelling, and eddy covariance and combined the observations with land surface and atmospheric models, adapted to the highland conditions. This allowed us to analyse how three degradation stages affect the water and carbon cycle of pastures on the landscape scale within the core region of the 
Kobresia pygmaea ecosystem. The study revealed that increasing degradation of the Kobresia turf affects carbon allocation and strongly reduces the carbon uptake, compromising the function of Kobresia pastures as a carbon sink. Pasture degradation leads to a shift from transpiration to evaporation while a change in the sum of evapotranspiration over a longer period cannot be confirmed. The results show an earlier onset of convection and cloud generation, likely triggered by a shift in evapotranspiration timing when dominated by evaporation. Consequently, precipitation starts earlier and clouds decrease the incoming solar radiation. In summary, the changes in surface properties by pasture degradation found on the highland have a significant influence on larger scales.

\section{Introduction}

Alpine ecosystems are considered as being highly vulnerable to the impacts of climate and land use change. This is especially the case for two of the world's highest and largest alpine ecosystems: the Kobresia pygmaea pastures covering $450000 \mathrm{~km}^{2}$ in the southeast and the alpine steppe covering $600000 \mathrm{~km}^{2}$ in the northwest of the Tibetan Plateau. The Kobresia pygmaea pastures typically form a closed grazing lawn of about $2 \mathrm{~cm}$ in height with up to $98 \%$ cover of $\mathrm{Ko}$ bresia pygmaea, as main constituent of a felty turf (Kaiser et al., 2008; Miehe et al., 2008b). The alpine steppe is a central Asian short grass steppe with alpine cushions and a plant cover declining from $40 \%$ in the east to $10 \%$ in the west (Miehe et al., 2011). Both ecosystems are linked by an ecotone of $200 \mathrm{~km}$ in width over $2000 \mathrm{~km}$ length (Fig. 1).

Obvious features of degradation in the Kobresia pastures and their ecotone are controversially discussed as being caused by either natural abiotic and biotic processes or human impacts (Zhou et al., 2005). The most widespread pattern are mosaics of: (i) closed Kobresia grazing lawns (later named as intact root Mat, IM); (ii) root turf that is only sparsely vegetated by Kobresia pygmaea but sealed with Cyanophyceae (later named as partly degraded root Mat, DM); and (iii) open loess and gravels that are sparely colonised by cushions, rosettes and small grasses of the alpine steppe (later named as bare soil, BS).

Assessments of pasture degradation have been either based on biotic parameters such as decreasing vegetation cover, species diversity, productivity and forage quality, or alternatively on abiotic factors including nutrient loss, soil compaction and ongoing soil erosion (Harris, 2010). A definition of degradation stages was given by Liu et al. (2003, in Chinese) and later on used by Zhou et al. (2005). According to a study by Niu (1999), 30\% of the Kobresia grassland is degraded at various levels. Holzner and Kriechbaum (2000) reported that about $30 \%$ is in optimal condition, about $30 \%$ shows characteristics of overgrazing where regeneration seems to be possible after improved utilisation and about $40 \%$ shows recent or ancient complete degradation. Here, we regard bare silty soil as the final degradation stage of a former Kobresia pasture with its intact root turf. Loss of Kobresia cover goes along with a decrease of palatable species and thus pasture quality.

The general lack of data on the alpine ecology of Kobresia pastures is in strong contrast to the relevance of this ecosystem. However, it is important not only to gain more knowledge on single aspects of the Kobresia pasture, but especially on ecological functions of the ecosystem. Therefore, modelling of the effects of degradation on atmospheric processes as well as more general analysis of interactions is necessary (Cui and Graf, 2009). Only when this challenge has been met can the effect be investigated in climate models, both for the past, but mainly for a future climate. The model simulations of Cui et al. (2006) clearly demonstrate that anthropogenic land use change on the Tibetan Plateau has far reaching implications for the Indian and East Asian summer monsoons. In order to correctly reproduce the hydrological regime on the plateau, a spatial resolution of the order of $10 \mathrm{~km}$ is required (Cui et al., 2007b). This resolution is typical for stateof-the-art weather forecast models, but is by far not reached by any climate model simulation. This lack of scale compatibility can to some degree be compensated by sophisticated treatment of surface energy fluxes and their impact on convective clouds. Therefore, there is an urgent need to identify the parameters and factors influencing the pastures and to quantify energy and matter fluxes.

In order to model fluxes over Kobresia and degraded areas, it is necessary to identify those model parameters which change significantly due to any degradation present. Three factors could reflect these problems:

- Missing vegetation: the difference is considered in the simulation through the fraction of vegetated areas and the respective parameter differences between bare soil evaporation and grassland evapotranspiration, as well as assimilation and respiration.

- Different soil properties: due to the missing Kobresia turf, soil properties of the upper layer might be changed: less living and dead organic material lead to poor isolation and switch from hydrophobic to more hydrophilic properties, thus leading to higher infiltration capacity and higher soil hydraulic conductivity.

- The available energy changes mostly due to albedo differences and outgoing long-wave radiation. Furthermore, the direct solar irradiation is much larger than diffuse radiation compared to other regions of the world.

We expect that degradation of vegetation and soil surface at the plot scale leads to changes of water and carbon fluxes, as well as carbon stocks, at the ecosystem level, with consequences for the whole Tibetan Plateau. The aim of this study was to analyse and model for the first time the water 


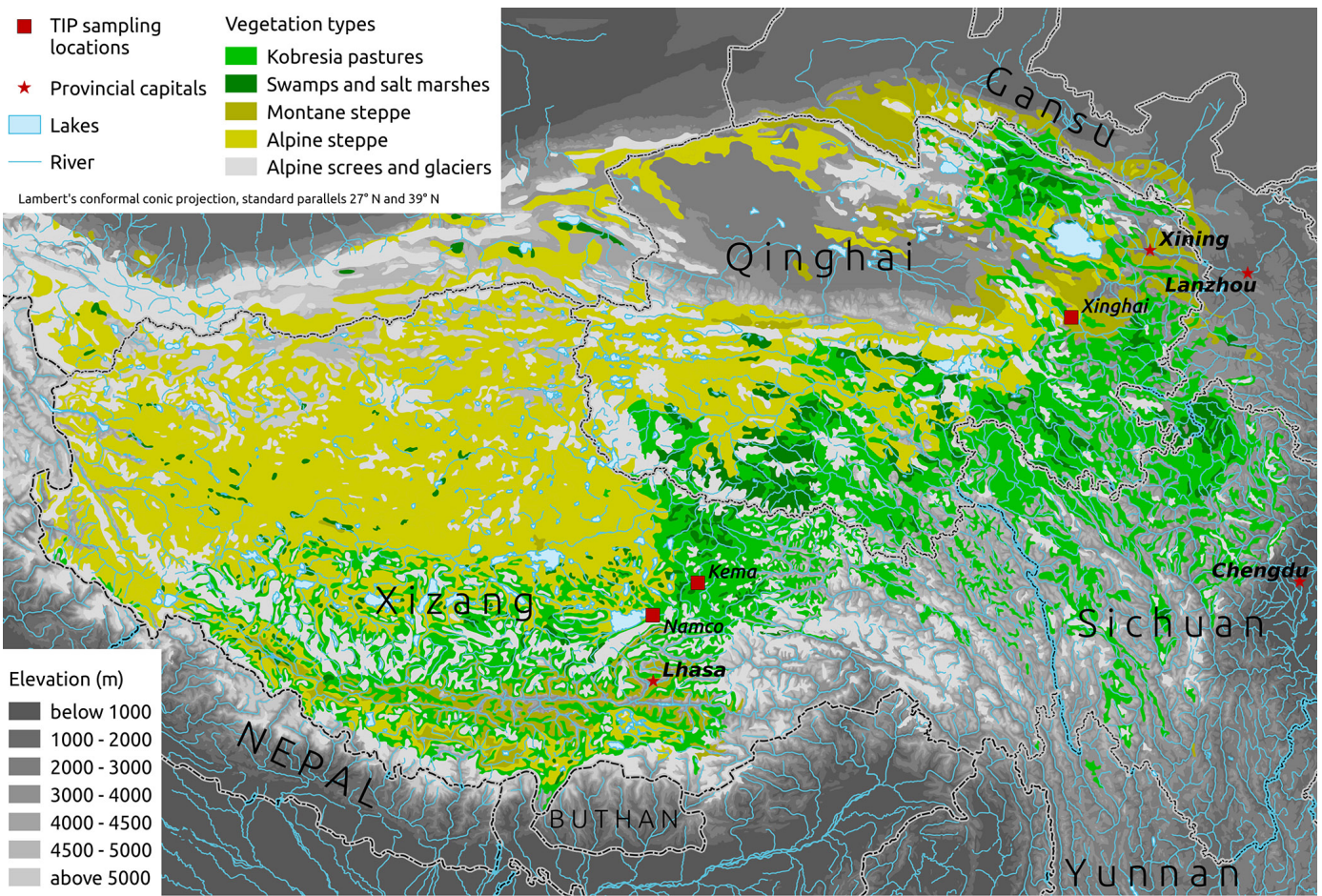

Figure 1. Kobresia pygmaea pastures (in green) dominate the southeastern quarter of the Tibetan highlands, whereas the alpine steppe covers the arid northwestern highlands. The experimental sites Xinghai and Kema are in montane and alpine Kobresia pastures, whereas the Nam Co site is situated in the ecotone towards alpine steppe (modified after Miehe et al., 2008b).

and carbon fluxes in the above-mentioned three types of surface patterns of Kobresia pastures on the Tibetan Plateau. We combine the benefits of observing water and carbon fluxes at the plot scale, using micro-lysimeter, chamber-based gas exchange measurements and ${ }^{13} \mathrm{CO}_{2}$ labelling studies, and also simultaneously at the ecosystem scale with eddy-covariance measurements. Our model studies are focused on land surface models, where the description of plant and soil parameters is more explicitly parameterised than in larger-scale models. They bridge between the plot and the ecosystem scale and simulate the influence of increasing degradation on water and carbon fluxes, which ultimately leads to changes of cloud cover and precipitation. Explicitly simulating the impact of changes in vegetation on turbulent surface fluxes (Gerken et al., 2012), local to regional circulation (Gerken et al., 2014) and variability in the evolution of convective clouds and rainfall due to different tropospheric vertical profiles (Gerken et al., 2013) allows for the assessment of the sensitivity of the energetic and hydrological regimes on the Tibetan Plateau. Such model simulations on the local scale serve as an important tool for the interpretation of larger scale simulations and sensitivity studies. The current study provides a link between degradation studies (Harris, 2010) and remote sensing and modelling for the whole Tibetan Plateau (Ma et al., 2011, 2014; Maussion et al., 2014; Shi and Liang,
2014) and climate studies (Cui et al., 2006, 2007a; Yang et al., 2011; Yang et al., 2014).

\section{Material and methods}

\subsection{Study sites}

For the present study, measurements were taken at three study sites on the Tibetan Plateau. Details are given in Table 1. For the experimental activities at the sites see Sect. 2.5.

Xinghai: The experimental site is located in Qinghai province in the northeastern Tibetan Plateau, approximately $200 \mathrm{~km}$ southwest of Xining, and about $15 \mathrm{~km}$ south of Xinghai city. The montane grassland has developed on a loess-covered $(1.2 \mathrm{~m})$ terrace of the Huang He River. The grassland is used as a winter pasture for yaks and sheep for 6-7 months of the year (Miehe et al., 2008b; Unteregelsbacher et al., 2012). About $20 \%$ of the pasture at the experiment site is completely covered with blue-green algae and crustose lichens.

Kema: The "Kobresia pygmaea Research Station Kema", established in 2007, is located in the core area of alpine $\mathrm{Ko}$ bresia pygmaea pasture. All measurements were established either within or in the close surroundings of an area of $100 \mathrm{~m}$ 
Table 1. Characteristics of the three study sites.

\begin{tabular}{|c|c|c|c|c|}
\hline & Xinghai & Kema & \multicolumn{2}{|c|}{ Nam Co } \\
\hline Coordinates & $35^{\circ} 32^{\prime} \mathrm{N}, 99^{\circ} 51^{\prime} \mathrm{E}$ & $31^{\circ} 16^{\prime} \mathrm{N}, 92^{\circ} 06^{\prime} \mathrm{E}$ & \multicolumn{2}{|c|}{$30^{\circ} 46^{\prime} \mathrm{N}, 90^{\circ} 58^{\prime} \mathrm{E}$} \\
\hline Altitude a.s.l. & $3440 \mathrm{~m}$ & $4410 \mathrm{~m}$ & \multicolumn{2}{|c|}{$4730 \mathrm{~m}$} \\
\hline Soil (IUSS-ISRIC-FAO, & Haplic & Stagnic (mollic) & \multirow{2}{*}{\multicolumn{2}{|c|}{ Stagnic Cambisols and Arenosol }} \\
\hline 2006) & Kastanozems & Cambisol & & \\
\hline Pasture type & $\begin{array}{l}\text { Montane Kobresia- } \\
\text { Stipa winter pas- } \\
\text { tures }\end{array}$ & $\begin{array}{l}\text { Alpine Kobresia } \\
\text { pygmaea pastures }\end{array}$ & \multicolumn{2}{|c|}{$\begin{array}{l}\text { Alpine steppe pastures with } \\
\text { mosaic Kobresia turfs }\end{array}$} \\
\hline $\begin{array}{l}\text { Source for soil and } \\
\text { plant types }\end{array}$ & $\begin{array}{l}\text { Kaiser et al. (2008), } \\
\text { Miehe et al. (2008a), } \\
\text { Unteregelsbacher } \\
\text { et al. (2012), and } \\
\text { Hafner et al. (2012) }\end{array}$ & $\begin{array}{l}\text { This study, Kaiser } \\
\text { et al. (2008), Miehe } \\
\text { et al. (2011), and } \\
\text { Biermann et al. } \\
(2011,2013)\end{array}$ & \multicolumn{2}{|c|}{ Kaiser et al. (2008), and Miehe et al. (2014) } \\
\hline Climate period & $1971-2000$ & $1971-2000$ & 1971-2000 & 1971-2000 \\
\hline \multirow{2}{*}{ Climate station } & Xinghai & $\mathrm{Naqu}$ & Baingoin & Damxung \\
\hline & $\begin{array}{l}3323 \text { ma.s.1., } \\
35^{\circ} 35^{\prime} \mathrm{N}, 99^{\circ} 59^{\prime} \mathrm{E}\end{array}$ & $\begin{array}{l}4507 \text { ma.s.1., } \\
31^{\circ} 29^{\prime} \mathrm{N}, 92^{\circ} 04^{\prime} \mathrm{E}\end{array}$ & $\begin{array}{l}4700 \mathrm{~m} \text { a.s.1., } \\
31^{\circ} 23^{\prime} \mathrm{N}, 90^{\circ} 01^{\prime} \mathrm{E}\end{array}$ & $\begin{array}{l}4200 \text { ma.s.1., } \\
30^{\circ} 29^{\prime} \mathrm{N}, 91^{\circ} 06^{\prime} \mathrm{E}\end{array}$ \\
\hline Annual precipitation* & $353 \mathrm{~mm}$ & $430 \mathrm{~mm}$ & $322 \mathrm{~mm}$ & $460 \mathrm{~mm}$ \\
\hline Mean annual temperature & $1.4^{\circ} \mathrm{C}$ & $-1.2^{\circ} \mathrm{C}$ & $-0.8^{\circ} \mathrm{C}$ & $1.7^{\circ} \mathrm{C}$ \\
\hline Mean Jul temperature & $12.3^{\circ} \mathrm{C}$ & $9.0^{\circ} \mathrm{C}$ & $8.7^{\circ} \mathrm{C}$ & $10.9^{\circ} \mathrm{C}$ \\
\hline $\begin{array}{l}\text { Source for climate } \\
\text { data }\end{array}$ & \multicolumn{4}{|c|}{ http://cdc.cma.gov.cn/ } \\
\hline
\end{tabular}

* Due to the East Asian monsoon, almost all of the precipitation falls in the summer months from May to Sep, most frequently in the form of torrential rain during afternoon thunderstorms.

Table 2. Criteria for a differentiation of main degradation classes at Kema site and survey results.

\begin{tabular}{|c|c|c|c|}
\hline Stage & $\begin{array}{l}\text { Intact root } \\
\text { Mat (IM) }\end{array}$ & $\begin{array}{l}\text { Degraded root } \\
\text { Mat (DM) }\end{array}$ & $\begin{array}{l}\text { Bare soil } \\
\quad(\mathrm{BS})\end{array}$ \\
\hline Dominant plant species & Kobresia pygmaea & $\begin{array}{l}\text { Kobresia pygmaea, } \\
\text { Lichens, Algae }\end{array}$ & $\begin{array}{l}\text { Annuals, e.g. } \\
\text { Axyris prostrata }\end{array}$ \\
\hline Root mat layer & Yes & Yes & No \\
\hline $\begin{array}{l}\text { Proportion of total surface } \\
\text { area }(\%, n=2618)^{*}\end{array}$ & 65 & 16 & 19 \\
\hline $\begin{array}{l}\text { Mean vegetation cover within } \\
\text { the respective stage }(\%)^{*}\end{array}$ & $88 \pm 6(\mathrm{SD})$ & $26 \pm 10(\mathrm{SD})$ & $12 \pm 8(\mathrm{SD})$ \\
\hline $\begin{array}{l}\text { Maximal vegetation cover } \\
(\%)^{*}\end{array}$ & 99 & 65 & 35 \\
\hline $\begin{array}{l}\text { Minimal vegetation cover } \\
(\%)^{*}\end{array}$ & 72 & 5 & 0 \\
\hline $\begin{array}{l}\text { Level difference to BS } \\
(\mathrm{cm}, n=60)\end{array}$ & $9.4 \pm 2.0(\mathrm{SD})$ & $8.5 \pm 2.0(\mathrm{SD})$ & - \\
\hline
\end{tabular}

* $n=100$ for IM, DM, BS; considered are only "higher graduated plants" (grasses, herbs).

by $250 \mathrm{~m}$, fenced in 2009 , on a pasture where grazing was restricted to a few months during winter and spring. The growing season strongly depends on the availability of water, and usually starts at the end of May with the onset of the monsoon and ends with longer frosts by the end of August or September. Kobresia pygmaea has an average vegetation grazed height of $1-2 \mathrm{~cm}$ (Miehe et al., 2008b) and forms a very tough felty root turf of living and dead Kobresia roots, leaf bases and soil organic matter (Kaiser et al., 2008). It is designated as Kobresia root mat throughout this study and attains a thickness of $14 \mathrm{~cm}$.

The site is covered with Kobresia pygmaea (Cyperaceae), accompanied by other monocotyledons (Carex ivanoviae, Carex spp., Festuca spec., Kobresia pusilla, Poa spp., Stipa purpurea) and to a minor degree by perennial herbs. For more details on the species diversity see Biermann et al. (2011, 2013).

Nam Co: The "Nam Co Monitoring and Research Station for Multisphere Interactions" (NAMORS) of the Institute of 
Table 3. Instrumentation of Kema site in 2010 (6 June-2 August) and 2012 (11 July-10 September, AWS: automatic weather station).

\begin{tabular}{|c|c|c|c|c|c|}
\hline & $\begin{array}{l}\text { Complex } 1 \\
\text { Kobresia pasture, } \\
2010\end{array}$ & $\begin{array}{l}\text { Complex } 2^{*} \\
\text { Kobresia pasture, } \\
2010\end{array}$ & $\begin{array}{l}\text { Complex } 3 \\
\text { bare soil } \\
2010\end{array}$ & $\begin{array}{l}\text { AWS } \\
2012\end{array}$ & $\begin{array}{l}\text { Radiation and } \\
\text { soil complex } \\
2012\end{array}$ \\
\hline $\begin{array}{l}\text { Wind velocity and wind } \\
\text { direction }\end{array}$ & $\begin{array}{l}2.21 \text { m, CSAT3 } \\
\text { (Campbell Sci. Ltd.) }\end{array}$ & $\begin{array}{l}2.20 \text { m, CSAT3 } \\
\text { (Campbell Sci. Ltd.) }\end{array}$ & - & $\begin{array}{l}2.0 \mathrm{~m} \text {, WindSonic } \\
1 \text { (Gill) }\end{array}$ & - \\
\hline $\begin{array}{l}\mathrm{CO}_{2} \text { and } \mathrm{H}_{2} \mathrm{O} \\
\text { concentration }\end{array}$ & $\begin{array}{l}2.16 \mathrm{~m}, \mathrm{LI}-7500 \\
\text { (LI-COR Biosciences) }\end{array}$ & $\begin{array}{l}2.19 \mathrm{~m}, \quad \text { LI- } 7500 \\
\text { COR Biosciences) }\end{array}$ & - & - & - \\
\hline $\begin{array}{l}\text { Air temperature and } \\
\text { humidity }\end{array}$ & $\begin{array}{l}2.20 \mathrm{~m}, \mathrm{HMP} 45 \\
\text { (Vaisala) }\end{array}$ & $\begin{array}{l}2.20 \mathrm{~m}, \mathrm{HMP} 45 \\
\text { (Vaisala) }\end{array}$ & - & $\begin{array}{l}2.0 \mathrm{~m}, \mathrm{CS} 215 \\
\text { (Campbell Scientific } \\
\text { Ltd.) }\end{array}$ & - \\
\hline Ambient pressure & - & $\begin{array}{l}\text { Inside Logger Box } \\
\text { (Vaisala) }\end{array}$ & - & - & - \\
\hline Solar radiation & $\begin{array}{l}1.90 \mathrm{~m}, \text { CNR1 (Kipp \& } \\
\text { Zonen) }\end{array}$ & $\begin{array}{l}1.88 \text { m; CNR1 } \\
\text { (Kipp \& Zonen) }\end{array}$ & - & $\begin{array}{l}2.0 \mathrm{~m} \text {, Pyranometer SP } \\
110 \text { (Apogee), NR Lite } \\
\text { (Kipp \& Zonen), } \\
\text { LI } 190 \text { SB (LI-COR) }\end{array}$ & $\begin{array}{l}2.0 \mathrm{~m} ; \mathrm{CNR} 1 \\
\text { (Kipp \& Zo- } \\
\text { nen) }\end{array}$ \\
\hline Precipitation & - & $\begin{array}{l}1.0 \mathrm{~m} \text {, Tipping } \\
\text { bucket }\end{array}$ & - & $\begin{array}{l}0.5 \mathrm{~m} \text {, Tipping } \\
\text { Bucket (Young) }\end{array}$ & - \\
\hline Soil moisture & $\begin{array}{l}-0.15 \\
\text { Imko-TDR }\end{array}$ & $\begin{array}{l}-0.1 \\
-0.2 \\
\text { Imko-TDR }\end{array}$ & $\begin{array}{l}-0.15 \\
\text { Imko-TDR }\end{array}$ & $\begin{array}{l}-0.05, \\
-0.125, \\
-0.25, \text { Campbell CS } 616\end{array}$ & $\begin{array}{l}-0.1 \\
-0.2 \\
\text { Imko-TDR }\end{array}$ \\
\hline Soil water potential & - & - & - & $\begin{array}{l}-0.05 \\
-0.125 \\
-0.25, \text { Campbell 257-L }\end{array}$ & - \\
\hline Soil temperature & $\begin{array}{l}-0.025, \\
-0.075 \\
-0.125, \\
\text { Pt } 100\end{array}$ & $\begin{array}{l}-0.025 \\
-0.075 \\
-0.125 \\
-0.2 \\
\text { Pt } 100\end{array}$ & $\begin{array}{l}-0.025, \\
-0.075 \\
-0.125 \\
\text { Pt } 100\end{array}$ & $\begin{array}{l}-0.025 \\
-0.075 \\
-0.125 \\
-0.25 \\
\text { Pt } 100\end{array}$ & $\begin{array}{l}-0.025 \\
-0.075 \\
-0.125 \\
-0.175 \\
\text { Pt } 100\end{array}$ \\
\hline Soil heat flux & $-0.15, \mathrm{HP} 3$ & $-0.15, \mathrm{HP} 3$ & $-0.15, \mathrm{HP} 3$ & - & $\begin{array}{l}-0.2, \quad \text { HP3, } \\
\text { Hukseflux }\end{array}$ \\
\hline
\end{tabular}

* This complex was used due to the higher data availability. There was no difference between the two instruments.

TibetanPlateauResearch of the Chinese Academy of Science (Ma et al., 2008) is located within an intramontane basin, $1 \mathrm{~km}$ SE of Lake Nam Co and in approximately $10 \mathrm{~km}$ distance NNW of the foot of the Nyainqentanglha mountain range. The zonal vegetation comprises mosaics of Kobresia turfs and open alpine steppe; water surplus sites have degraded Cyperaceae swamps (Mügler et al., 2010; Wei et al., 2012; Miehe et al., 2014).

\subsection{Classification of the degradation classes at Kema site}

At the Kema site a patchy structure of different degradation stages exists, which were classified according to the following classes (Fig. 2): intact root Mat (IM), degraded root Mat (DM) and bare soil (BS).

\section{Intact root Mat (IM)}

Although this degradation class is named as IM in this study, according to the definition of Miehe et al. (2008b) it is already degraded. Closed Kobresia mats are normally characterized as 90-98\% cover of Kobresia pygmaea, and additionally occurring biennial rosette species (Miehe et al., 2008b), which is not the case at Kema site. Nevertheless, soil is covered completely with the characteristic root turf of these Cyperaceae communities and a fairly closed cover of vegetation can be observed.

\section{Degraded root Mat (DM)}

For the DM class, not only is the spatial cover of Kobresia pygmaea much lower (less than $26 \%$ ), but also the proportion of crusts compared to IM is much higher; the root turf is still present. Crusts were formed by Cyanophyceae (blue algae, Miehe et al., 2008b; Unteregelsbacher et al., 2012) and were a characteristic property of this classification. 

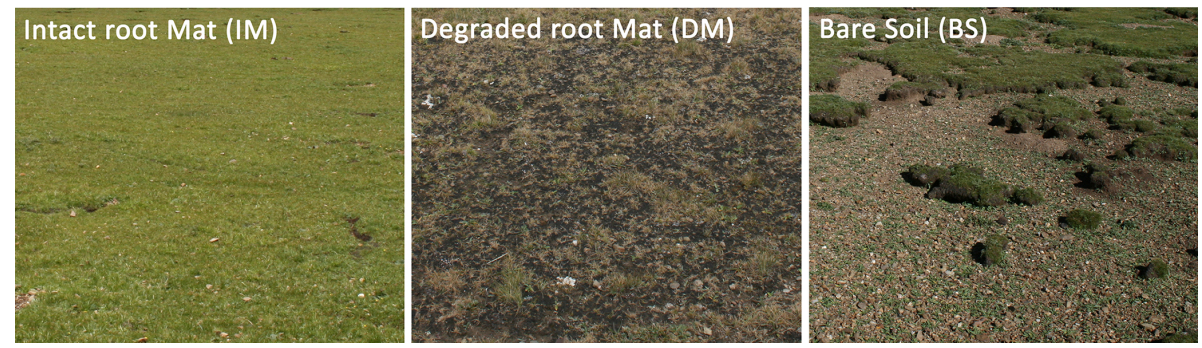

Figure 2. The three defined vegetation classes: (a) intact root Mat (IM); (b) degraded root Mat (DM); and (c) bare soil (BS).

\section{Bare soil (BS)}

In contrast to IM and DM, this surface class is missing the dense root turf and Kobresia pygmaea completely, resulting in a height step change. Most of the surface is unvegetated, nevertheless annual and perennial plants still occur, e.g. Lancea tibetica and Saussurea stoliczkai, described as endemic biennial rosettes and endemic plants with rhizomes, adapted to soil movement and the occurrence of trampling (Miehe et al., 2011).

These classes co-exist on scales which are too small to be resolved by the eddy-covariance method. Therefore we conducted a field survey within the eddy-covariance footprint to estimate their spatial abundance (Table 2). The degradation classes were recorded at a defined area of $5 \mathrm{~cm} \times 5 \mathrm{~cm}$ over a regular grid according to the step point method (Evans and Love, 1957), yielding a total of 2618 observations. The proportion of total surface area is then calculated from the frequency of a given class vs. the total number of sampling points. With a Kobresia pygmaea cover of approximately $65 \%$, an area of $16 \%$ crust-covered turf as well as $19 \%$ bare soil spots, the main study site is considered to be a typical alpine Kobresia pygmaea pasture with a low to medium degradation state (Table 2).

\subsection{Measuring methods}

\subsubsection{Micrometeorological measurements}

The measurements of the water and carbon fluxes with the eddy-covariance (EC) method were conducted at the Nam Co site in 2009 and at the Kema site in 2010. The EC towers were equipped with CSAT3 sonic anemometers (Campbell Sci. Inc.) and LI-7500 (LI-COR Biosciences) gas analysers. The complete instrumentation, including radiation and soil sensors, is given in Tables 3 and 4; for more details see Zhou et al. (2011) and Biermann et al. (2011, 2013).

Turbulent fluxes were calculated and quality controlled based on micrometeorological standards (Aubinet et al., 2012) through the application of the software package TK2/TK3 developed at the University of Bayreuth (Mauder and Foken, 2004, 2011). This includes all necessary data correction and data quality tools (Foken et al., 2012a), was ap- proved by comparison with other commonly used software packages (Mauder et al., 2008; Fratini and Mauder, 2014), and calculated fluxes match up-to-date micrometeorological standards (Foken et al., 2012a; Rebmann et al., 2012). It also offers a quality flagging system evaluating stationarity and development of turbulence (Foken and Wichura, 1996; Foken et al., 2004). Furthermore, a footprint analysis was performed (Göckede et al., 2004, 2006), which showed that the footprint area was within the classified land use type. This finding is in agreement with the results obtained by Zhou et al. (2011) for the Nam Co site.

For the interpretation of the results, the so-called unclosure of the surface energy balance (Foken, 2008) with eddy-covariance data must be taken into account, especially when comparing eddy-covariance measurements with models that close the energy balance, like SEWAB (Kracher et al., 2009), or when comparing evapotranspiration sums with micro-lysimeter measurements. For the Nam Co site Zhou et al. (2011) found that only $70 \%$ of the available energy (net radiation minus ground heat flux) contributes to the sensible and latent heat flux, which is similar to the findings of other authors for the Tibetan Plateau (Tanaka et al., 2001; Yang et al., 2004). For the Nam Co 2009 data set we found a closure of $80 \%$, while both eddy-covariance measurements in Kema 2010 showed a closure of $73 \%$. Following recent experimental studies, we assume that the missing energy is to a large extent part of the sensible heat flux (Foken et al., 2011; Charuchittipan et al., 2014), which was also postulated from a model study (Ingwersen et al., 2011). We thus corrected the turbulent fluxes for the missing energy according to the percentage of sensible and latent heat flux contributing to the buoyancy flux according to Charuchittipan et al. (2014), Eqns 21-23 therein. This correction method attributes most of the residual to the sensible heat flux depending on the Bowen ratio (see Charuchittipan et al., 2014, Fig. 8 therein). For the measured range of Bowen ratios from 0.12 (5\% quantile) to 3.3 (95\% quantile), 37 to $2 \%$ of the available energy was moved to the latent heat flux. For Kema in 2010 , this is equal to an addition of $5 \mathrm{~W} \mathrm{~m}^{-2}$ missing energy to the latent heat flux on average. In contrast, eddycovariance-derived net ecosystem exchange (NEE) fluxes were not corrected (Foken et al., 2012a). 
Table 4. Instrumentation of NamCo site in 2009 (25 June-8 August, only relevant instruments are shown).

\begin{tabular}{lll}
\hline Device & Type/manufacturer & Height \\
\hline Ultrasonic anemometer & CSAT3 (Campbell Scientific Ltd.) & $3.1 \mathrm{~m}$ \\
Gas analyser & LI-7500 (LI-COR Biosciences) & $3.1 \mathrm{~m}$ \\
Temperature-humidity sensor & HMP 45 (Vaisala) & $3.1 \mathrm{~m}$ \\
Net radiometer & CM3 \& CG3 (Kipp\&Zonen) & $1.5 \mathrm{~m}$ \\
Rain gauge & Tipping bucket & $1 \mathrm{~m}$ \\
Soil moisture & Imko-TDR & $-0.1,-0.2,-0.4,-0.8,-1.60$ \\
Soil temperature & Pt100 & $-0.2,-0.4,-0.8,-1.60$ \\
Logger & CR5000 (Campbell Scientific Ltd.) & \\
\hline
\end{tabular}

\subsubsection{Soil hydrological measurements}

In order to directly assess hydrological properties of the different degradation stages we used small weighing microlysimeters as a well-established tool to monitor evapotranspiration, infiltration and volumetric soil water content (Wieser et al., 2008; van den Bergh et al., 2013). As it was necessary to allow for quick installation with minimum disturbance, we developed a technique based on near-natural monoliths extracted in transparent plexiglass tubes (diameter $15 \mathrm{~cm}$, length $30 \mathrm{~cm}$ ). The monoliths were visually examined for intactness of the soil structure and artificial water pathways along the sidewall and then reinserted in their natural place inside a protecting outer tube (inner diameter $15 \mathrm{~cm}$ ).

A general problem with soil monoliths is the disruption of the flow paths to the lower soil horizons leading to artificially high water saturation in the lower part of the monolith (Ben-Gal and Shani, 2002; Gee et al., 2009). This was prevented by applying a constant suction with $10 \mathrm{hPa}$ of a hanging water column maintained by a spread bundle of 20 glass wicks ( $2 \mathrm{~mm}$ diameter) leading through the bottom plate into a $10 \mathrm{~cm}$ long downward pipe (15 mm diameter). Drained water was collected in a $200 \mathrm{ml} \mathrm{PE}$ bottle.

Micro-lysimeters were set up in June 2010 on four subplots inside the fenced area of the Kema site at a distance of 20 to $50 \mathrm{~m}$ from the eddy-covariance station. On each subplot one micro-lysimeter was installed in IM and one in BS at a maximum distance of $1 \mathrm{~m}$. All micro-lysimeters were weighed every 2 to 10 days with a precision hanging balance from 23 June to 5 September 2010 and from 2 June to 5 September 2012. Soil cores ( $3.3 \mathrm{~cm}$ diameter, $30 \mathrm{~cm}$ depth) were taken near every micro-lysimeter on 29 June 2010. The soil samples were weighed fresh and after drying in the laboratory at Lhasa. By relating the given water content to the weight of the corresponding micro-lysimeter at that date, we were able to calculate volumetric soil water content for each micro-lysimeter over the whole measuring period. Further details about the micro-lysimeter technique and set-up are given by Biermann et al. (2013).

\subsubsection{Soil gas exchange measurements}

In 2012, $\mathrm{CO}_{2}$ flux measurements were conducted with an automatic chamber system from LI-COR Biosciences (Lincoln, NE, USA). This LI-COR long-term chamber system contains a LI-8100 Infrared Gas Analyser (LI-COR Lincoln, NE, USA), is linked with an automated multiplexing system (LI-8150) and two automated chambers, one opaque and the other transparent for $R_{\text {eco }}$ and net ecosystem exchange (NEE), respectively. The chambers are equipped with a fully automatically rotating arm that moves the chamber $180^{\circ}$ away from the collar and therefore ensures undisturbed patterns of precipitation, temperature and radiation. Furthermore, by moving the chamber in-between measurements the soil and vegetation itself experiences less disturbance. The applied LI-COR chambers were compared during a separate experiment against eddy-covariance measurements by Riederer et al. (2014). Besides differences - mainly under stable atmospheric stratification - the comparison was satisfactory in daytime.

The three surface types IM, DM and BS were investigated with respect to their $\mathrm{CO}_{2}$ fluxes between 30 July and 26 August 2012 at Kema. The $\mathrm{CO}_{2}$-flux measurements of the three treatments were conducted consecutively. Therefore, the long-term chambers were moved to a patch representing the surface of interest. Measurements were conducted for 5 to 9 days before rotating to another location, starting from IM (30 July-7 August), continuing at BS (7-15 August), DM (15-21 August) and ending again at IM (21-26 August).

Intact root Mat has been measured twice during the observation period to provide information about possible changes in the magnitude of $\mathrm{CO}_{2}$ fluxes, due to changing meteorological parameters. The two measurements will be denoted as IM period 1 and IM period 4 . Note that during the measurement of IM period 4, other collars than during IM period 1 have been investigated. Nevertheless, the patches selected for the collar installation consisted of the same plant community, and showed the same soil characteristics. Because of lack of time the other two surfaces BS and DM were only measured once, but for as long as possible to gather sufficient information on diurnal cycles for these treatments. 


\subsection{4 ${ }^{13}$ C labelling}

${ }^{13} \mathrm{CO}_{2}$ pulse labelling experiments were used to trace allocation of assimilated $\mathrm{C}$ in the shoot-root-soil system in a montane Kobresia pygmaea pasture 2009 in Xinghai (Hafner et al., 2012) and in alpine Kobresia pygmaea pasture 2010 in Kema (Ingrisch et al., 2014). Plots $\left(0.6 \times 0.6 \mathrm{~m}^{2}\right)$ with plants were labelled with ${ }^{13} \mathrm{C}$-enriched $\mathrm{CO}_{2}$ in transparent chambers over $4 \mathrm{~h}$ at the periods of maximal Kobresia growth in summer. Afterwards, ${ }^{13} \mathrm{C}$ was traced in the plant-soil system over a period of 2 months with increasing sampling intervals (10 times).

Aboveground biomass was clipped and belowground pools were sampled with a soil core $(0-5 \mathrm{~cm}, 5-15 \mathrm{~cm}$ and in Xinghai additionally in $15-30 \mathrm{~cm}$ ). After drying and sieving $(2 \mathrm{~mm})$, two belowground pools were separated into soil and roots. As the only means of obtaining measurements of soil $\mathrm{CO}_{2}$ efflux and its $\delta^{13} \mathrm{C}$ in a remote location, the static alkali absorption method with installation of $\mathrm{NaOH}$ traps was used (Lundegardh, 1921; Singh and Gupta, 1977; Hafner et al., 2012). Natural ${ }^{13} \mathrm{C}$ abundance in the pools of plant-soil systems, including $\mathrm{CO}_{2}$ efflux, was sampled with a similar procedure on unlabelled spots. Total carbon and nitrogen content and $\delta^{13} \mathrm{C}$ of the samples were analysed with an Isotope-Ratio Mass Spectrometer. All details of the ${ }^{13} \mathrm{CO}_{2}$ pulse labelling experiments were described in Hafner et al. (2012) and Ingrisch et al. (2014). All data from ${ }^{13} \mathrm{C}$ labelling experiments are presented as means \pm standard errors. The significance of differences was analysed by ANOVA at $\alpha=0.05$.

\subsection{Soil-vegetation-atmosphere transfer models}

We conducted model experiments in order to estimate the impact of the defined degradation classes on water and carbon fluxes, including feedback on atmospheric circulation. Therefore three 1-D soil-vegetation-atmosphere transfer models were utilised to examine evapotranspiration (Sect. 2.4.1), carbon fluxes (Sect. 2.4.2), and surface feedbacks (Sect. 2.4.3). While the first two models were driven by measured standard meteorological forcing data, the latter is fully coupled to the atmosphere, which allows for feedbacks of land surface exchange to the atmosphere.

\subsubsection{Evapotranspiration - the SEWAB model}

To model the sensible and latent heat flux (evapotranspiration) the 1-D soil-vegetation-atmosphere transfer scheme SEWAB (Surface Energy and WAter Balance model) was applied (Mengelkamp et al., 1999, 2001). The soil temperature distribution is solved by the diffusion equation and vertical movement of soil water is described by the Richards equation (Richards, 1931). Relationships between soil moisture characteristics are given by Clapp and Hornberger (1978). Atmospheric exchange is given by bulk approaches, taking into account aerodynamic and thermal roughness lengths with re- spect to atmospheric stability (Louis, 1979). The latent heat flux is split up into vegetated surface flux and bare soil evaporation. The flux from vegetation is composed of wet foliage evaporation and transpiration of dry leaves. For the latter, the stomata resistance is constrained by minimum resistance and stress factors in a Jarvis-type scheme (Noilhan and Planton, 1989). In contrast to many other SVAT models, SEWAB parameterises all energy balance components separately and closes the energy balance by an iteration for the surface temperature using Brent's method.

\subsubsection{Carbon dioxide exchange - the SVAT-CN}

The model SVAT-CN (Reichstein, 2001; Falge et al., 2005) simulates $\mathrm{CO}_{2}$ and $\mathrm{H}_{2} \mathrm{O}$ gas exchange of vegetation and soil. It consists of a 1-D canopy model (Caldwell et al., 1986; Tenhunen et al., 1995), a 1-D soil physical model of water and heat fluxes (Moldrup et al., 1989, 1991), and a model of root water uptake (Reichstein, 2001). The model has been further developed with respect to soil gas emissions of $\mathrm{CO}_{2}$ and $\mathrm{N}_{2} \mathrm{O}$ from forest, grassland, and fallow (Reth et al., 2005a, b, c). In combination with a 3-D model, it has been used to simulate vertical profiles of latent heat exchange and successfully compared to vertical profiles of latent heat exchange in a spruce forest canopy (Staudt et al., 2011; Foken et al., 2012b). Plant canopy and soil are represented by several horizontally homogeneous layers, for which microclimate and gas exchange is computed. The soil module simulates unsaturated water flow according to Richards equation (Richards, 1931) parameterised with van Genuchten (1980) soil hydraulic parameters. $\mathrm{C}_{3}$ photosynthesis is modelled using the basic formulation described by Farquhar et al. (1980). Stomatal conductance is linked linearly to assimilation and environmental controls via the Ball-Berry equation (Ball et al., 1987). The slope of this equation (gfac) is modelled depending on soil matrix potential $(\Psi)$ in the main root layer.

\subsubsection{2-D atmospheric model - ATHAM}

For estimation of surface feedbacks the Hybrid vegetation dynamics and biosphere model (Friend et al., 1997; Friend and Kiang, 2005) was utilised, which is coupled to the cloudresolving Active Tracer High-resolution Atmospheric Model (ATHAM, Oberhuber et al., 1998; Herzog et al., 2003). In a separate work (Gerken et al., 2012), the SEWAB model compared well with Hybrid. The fully coupled system was successful in simulating surface-atmosphere interactions, mesoscale circulations and convective evolution in the Nam Co basin (Gerken et al., 2013, 2014). In a coupled simulation, surface fluxes of energy and moisture interact with the flow field. At the same time, wind speed as well as clouds, which modify the surface radiation balance, provide a feedback to the surface and modify turbulent fluxes. Such simulations can produce a complex system of interactions. 
Table 5. Experimental setup during the different experiments, with the corresponding measuring technique and the degree of degradation, (intact root Mat: IM, degraded root Mat: DM, bare soil: BS, alpine steppe: AS).

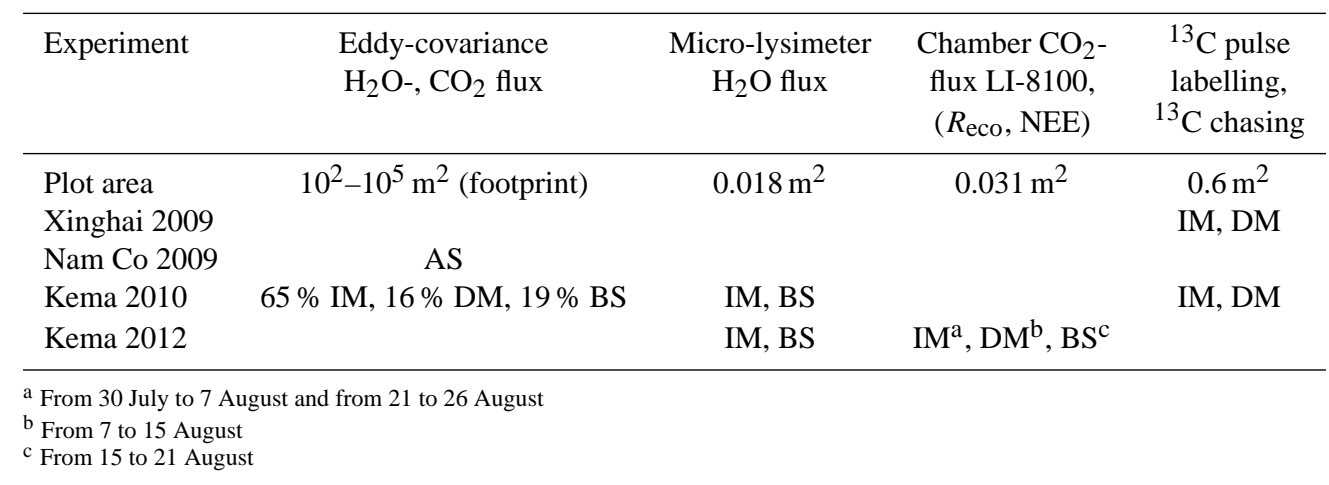

Table 6. Overview of model scenarios conducted with SEWAB and SVAT-CN for Kema site, periods 2010 and 2012 and Nam Co 2009. The numbers for vegetation fraction and the tile approach have been derived by the classification survey described in Sect. 2.2.

\begin{tabular}{llll}
\hline Simulation & $\begin{array}{l}\text { Proportion of } \\
\text { total surface area }\end{array}$ & $\begin{array}{l}\text { Vegetation } \\
\text { cover }\end{array}$ & $\begin{array}{l}\text { Model } \\
\text { parameter }\end{array}$ \\
\hline$S_{\mathrm{AS}}$ & $100 \%$ Alpine steppe & 0.6 & Nam Co AS \\
$S_{\mathrm{IM}}$ & $100 \% \mathrm{IM}$ & 0.88 & Kema RM \\
$S_{\mathrm{DM}}$ & $100 \% \mathrm{DM}$ & 0.26 & Kema RM \\
$S_{\mathrm{BS}}$ & $100 \% \mathrm{BS}$ & 0.12 & Kema BS \\
$S_{\mathrm{RefEC}}$ & Tile approach: & & \\
& $S_{\mathrm{RefEC}}=0.65 \cdot S_{\mathrm{IM}}+0.16$ & & \\
& $\cdot S_{\mathrm{DM}}+0.19 \cdot S_{\mathrm{BS}}$ & & \\
\hline
\end{tabular}

\subsubsection{Problems of land surface modelling on the Tibetan Plateau}

Land surface modelling of energy and carbon dioxide exchange faces specific problems on the Tibetan Plateau. Most influential is the strong diurnal cycle of the surface temperature, observed in dry conditions over bare soil or very low vegetation, leading to overestimation of surface sensible heat flux (Yang et al., 2009; Hong et al., 2010) caused by too high turbulent diffusion coefficients. Land surface models usually parameterise these coefficients by a fixed fraction between the roughness length of momentum and heat, however, Yang et al. (2003) and Ma et al. (2002) observed a diurnal variation of the thermal roughness length on the Tibetan Plateau. As another special feature, land surface models tend to underestimate bare soil evaporation in semiarid areas (e.g. Agam et al., 2004; Balsamo et al., 2011).

Especially the Kobresia mats are characterised by changing fractions of vegetation cover and partly missing root mats, exposing almost bare soil with properties different from the turf below the Kobresia. From investigations of soil vertical heterogeneity by Yang et al. (2005) it can be concluded that such variations will significantly influence the exchange processes, posing a challenge for land surface mod- elling. The models have therefore been adapted to these conditions and specific parameter sets have been elaborated from field measurements for Nam Co and Kema (Gerken et al., 2012; Biermann et al., 2014), see Appendix A for more details.

\subsection{Experimental and modelling concept}

Experimental investigations on the Tibetan Plateau are not comparable with typical meteorological and ecological experiments. Not only do the high altitude and the remoteness of the area impose limitations, but also unforeseeable administrative regulations challenge the organisation of experiments with different groups and large equipment. It was initially planned to investigate small degraded plots with chambers and micro-lysimeters and to use a larger plot, in the size of the eddy-covariance footprint, as a reference area to investigate the daily fluctuations of the evaporation and carbon dioxide flux. Due to customs and permit problems, this was unfortunately only partly possible at Kema site in 2010, and not at all during the main chamber experiment in 2012.

Therefore, model-specific parameters were investigated in 2012 and the models were adapted to the specific Tibetan conditions with the chamber data. These model versions were then tested with the eddy-covariance data in 2010 at the Kema site with nearly intact Kobresia cover. Forced with measured atmospheric conditions, these simulations are used to examine the differences among degradation classes in carbon and water exchange between surface and atmosphere. The ${ }^{13} \mathrm{C}$ labelling studies enabled us to relate the differences in carbon exchange to the specific vegetation and soil compartments. Finally, a surface scheme coupled with a mesoscale atmospheric model served to estimate feedbacks of surface forcing on the atmosphere. A summary of the experimental setup according to measurement technique is given in Table 5.

In accordance with this concept, we adapted both SEWAB and SVAT-CN to the Kema site using the vegetation and soil parameters elaborated in 2012, and chamber measurements 
Table 7. Comparison of the models SEWAB and SVAT-CN against eddy-covariance and chamber measurements, using the squared Pearson correlation coefficient $\mathrm{r}^{2}$, as well as slope and offset of the linear regression; $n$ is the number of observations

\begin{tabular}{lllllllll}
\hline Experiment & Comparison & Class & Variable & Unit & $\mathrm{r}^{2}$ & Slope & Offset & $n$ \\
\hline \multirow{2}{*}{ Nam Co 2009 } & EC vs. SEWAB & $\mathrm{AS}$ & $30 \mathrm{~min} \mathrm{ET}^{\mathrm{a}}$ & $\mathrm{mm} \mathrm{d}^{-1}$ & 0.74 & 1.10 & -0.50 & 572 \\
& EC vs. SVAT-CN & $\mathrm{AS}$ & Median NEE & $\mathrm{g} \mathrm{C} \mathrm{m}^{-2} \mathrm{~d}^{-1}$ & 0.90 & 1.15 & -0.15 & 124 \\
\hline \multirow{2}{*}{ Kema 2010 } & EC vs. SEWAB & RefEC & 30 min ET & $\mathrm{mm} \mathrm{d}^{-1}$ & 0.72 & 1.03 & -0.28 & 577 \\
& EC vs. SVAT-CN & RefEC & Median NEE & $\mathrm{g} \mathrm{C} \mathrm{m}^{-2} \mathrm{~d}^{-1}$ & 0.81 & 0.99 & -0.02 & 124 \\
\hline \multirow{2}{*}{ Kema 2012 } & Chamber vs. & $\mathrm{IM}$ & 30 min NEE & $\mathrm{g} \mathrm{C} \mathrm{m}^{-2} \mathrm{~d}^{-1}$ & 0.86 & 0.80 & -0.89 & 537 \\
& SVAT-CN & DM & 30 min NEE & $\mathrm{g} \mathrm{C} \mathrm{m}^{-2} \mathrm{~d}^{-1}$ & 0.74 & 0.85 & -0.24 & 363 \\
& & BS & 30 min NEE & $\mathrm{g} \mathrm{C} \mathrm{m}^{-2} \mathrm{~d}^{-1}$ & 0.48 & 1.77 & -0.38 & 195 \\
\hline
\end{tabular}

\footnotetext{
a ET at Nam Co 2009 is already published by Biermann et al. (2014), offset recalculated in $\mathrm{mm} \mathrm{d}^{-1}$

${ }^{b}$ Hourly medians from an ensemble diurnal cycle over the entire period

c Both period 1 and period 4
}

from 2012 for calibration. Two parameter sets were established: one for surfaces with root mat (Kema RM: IM and DM differ only in vegetation fraction), and one for BS conditions (Kema BS). Simulations with in situ measured atmospheric forcing data were performed specifically for each of the degradation classes $S_{\mathrm{IM}}, S_{\mathrm{DM}}$ and $S_{\mathrm{BS}}$ according to the definition in Table 2. These model runs serve to expand the chamber data beyond their measurement period, and we are now able to compare the class-specific fluxes over a 46-day period (12 July to 26 August 2012).

Furthermore, we compared the adapted model versions with eddy-covariance data from 2010 using the respective forcing data measured in situ in 2010. The eddy-covariance measurements integrate the fluxes from a source area ranging 50-200 $\mathrm{m}$ around the instrument (for detailed footprint analysis see Biermann et al., 2011, 2013), and therefore represent $\mathrm{H}_{2} \mathrm{O}$ and $\mathrm{CO}_{2}$ fluxes from IM, DM and BS according to their proportion of total surface area in Table 2. In order to ensure comparability, we reproduce this composition with the simulations as well using the tile approach $\left(S_{\text {RefEC }}\right)$. An overview of model scenarios conducted at the Kema site is given in Table 6.

The differences in flux simulations among the degradation stages were controlled by the variation of the vegetation fraction and soil properties. A consistent parameter set for several experiments and multiple target variables (evapotranspiration, net/gross ecosystem exchange, ecosystem respiration) is a necessary pre-condition to ensure that the model physics implemented reflect these changes in a realistic manner. Therefore we abstained from optimising the parameter space, but used parameter estimates from field and laboratory measurements as far as possible (Appendix A), and inevitable calibration has been done for SVAT-CN by scaling the leaf area index with a single factor as well as a complete set of leaf physiology parameters.

For the investigation of the impact of surface degradation on the atmosphere, it was decided to run a relatively simple numerical experiment prescribing a symmetric, twodimensional Tibetan valley with $150 \mathrm{~km}$ width, and surrounded by Gaussian hills with $1000 \mathrm{~m}$ altitude. A sounding taken at Nam Co on 17 July 2012 was used as the initial profile. The setup is comparable to Gerken et al. $(2013,2014)$. A total of four cases were chosen for this preliminary analysis. A dry scenario with initial soil moisture of $0.5 \times$ field capacity and a wet scenario with soil moisture at field capacity, as might be the case during the monsoon season, were used. For both surface states, simulations were performed with a vegetation cover of 25 and $75 \%$ corresponding to a degraded and intact soil-mat scenario.

The study is limited by conceptual restrictions, which are mainly due to the scale problem in the different compartments (Foken et al., 2012b, see Appendix of this paper) and the working conditions in remote and high altitudes. Only one more-or-less uniform type of degradation has been investigated within the footprint area of the eddy-covariance measurements (Göckede et al., 2006) of 50-200 m extent, which is, in the case of this study, an almost non-degraded Kobresia pasture. The other types could only be found on much smaller plots, and had no significant influence on the whole footprint area, even when the non-linear influence of the different land-cover areas on the fluxes of the larger area is considered (Mölders, 2012). However, the investigation of degraded stages could only be done with small-scale measurements, such as those obtained with chambers and microlysimeters.

\section{Results and discussion}

We used separate experiments in 2009 (Nam Co) and 2010 (Kema) to validate models against eddy-covariance data (Sect. 3.1). These models were compared in 2012 against micro-lysimeters (Sect. 3.2) and against chambers (Sect. 3.3). The specific results - in the sense of our research questions - are given in Sects. 3.4-3.6. 


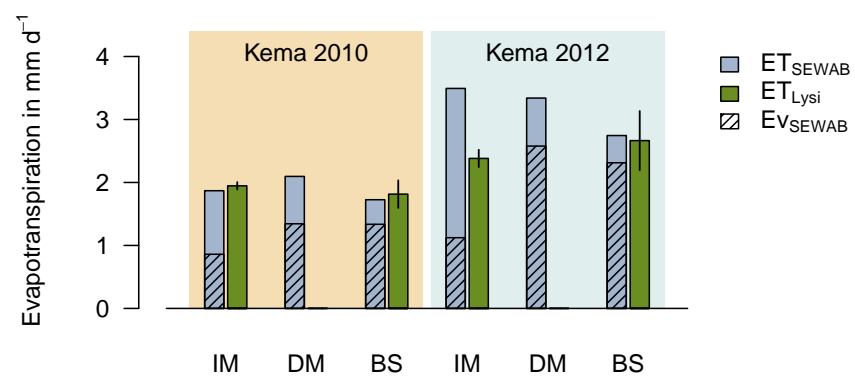

Figure 3. Evapotranspiration (ET) derived with SEWAB and with micro-lysimeter measurements at Kema in 2010 (33 days: 23 June-25 July) and Kema in 2012 (40 days: 16 July-24 August) for intact root mat (IM), degraded root Mat (DM) and bare soil (BS). Hatched bars denote the simulated evaporation (Ev) as part of the total simulated ET, the remainder is transpiration. Black lines on top of the bars for the micro-lysimeter illustrate standard deviations $(n=4)$.

\subsection{Comparison of eddy-covariance flux measurements with modelled fluxes}

In order to test the performance of evapotranspiration (ET) with SEWAB and net ecosystem exchange (NEE) with SVAT-CN, we compared the model results for Kema with the eddy-covariance measurements from 2010 (Sect. 2.5). The results show that SEWAB simulations represent the halfhourly measured turbulent fluxes at Kema generally well (Table 7, see scatter plots and diurnal cycles in the Appendix, Figs. B1-B5). Model performance at Nam Co for the measurements in 2009 was very similar, as well as the magnitude of the fluxes (Table 7, from Biermann et al., 2014). Measured hourly medians (from an ensemble diurnal cycle over the entire period) of NEE at Kema ranged between -2.8 and $1.5 \mathrm{~g} \mathrm{Cm}^{-2} \mathrm{~d}^{-1}$ over the course of the day, whereas modelled medians reached a minimum -3.0 and a maximum of $1.7 \mathrm{~g} \mathrm{C} \mathrm{m}^{-2} \mathrm{~d}^{-1}$. Although the model overestimated the $\mathrm{CO}_{2}$ uptake, especially in the midday hours, the correlation between hourly medians of model output and measured NEE was generally realistic (Table 7). Compared to Kema data, mean diurnal patterns of measured and modelled NEE at Nam Co site showed smaller fluxes and less variation. Measured hourly medians of NEE ranged between -2.3 and $1.0 \mathrm{~g} \mathrm{C} \mathrm{m}^{-2} \mathrm{~d}^{-1}$ over the course of the day, and modelled medians between -2.7 and $1.0 \mathrm{~g} \mathrm{Cm}^{-2} \mathrm{~d}^{-1}$ (Table 7).

\subsection{Class-specific comparison of evapotranspiration with micro-lysimeter measurements and SEWAB simulations}

Daily evapotranspiration (ET) of the Kobresia pygmaea ecosystem was about $2 \mathrm{mmd}^{-1}$ during dry periods and increased to $6 \mathrm{mmd}^{-1}$ after sufficient precipitation (not shown). This was confirmed with small weighable microlysimeters giving a direct measure of ET from small soil columns over several days and SEWAB simulations. For a 33-day period at Kema 2010, ET for both micro-lysimeter and simulations varied around $1.9 \mathrm{~mm} \mathrm{~d}^{-1}$, reflecting drier conditions, while in 2012 the micro-lysimeter showed a maximum ET of $2.7 \mathrm{mmd}^{-1}$ at BS, and the simulations $3.5 \mathrm{~mm} \mathrm{~d}^{-1}$ at IM (Fig. 3). In both periods, the lysimeter measurements do not differ significantly between IM and BS (two-sided Wilcoxon rank sum test, $n=4$ ). The model results support this finding in general, as they are within the $95 \%$ confidence interval $(1.96 \times$ standard error $)$ of the lysimeter measurements in three cases; however they differ significantly from the lysimeter measurements for IM in 2012. The model results suggest that even for dense vegetation cover (IM), a considerable part of ET stems from evaporation. At DM and BS, transpiration of the small aboveground part of Kobresia is lower, but it is compensated by evaporation. Therefore, the water balance is mainly driven by physical factors, i.e. atmospheric evaporative demand and soil water content.

\subsection{Class-specific comparison of carbon fluxes with chamber measurements and SVAT-CN simulations}

During the Kema 2012 campaign, the carbon fluxes for different degradation levels were investigated with chamberbased gas exchange measurements. Parallel measurements could not be established due to instrumental limitations, therefore the SVAT-CN model is utilised to compare the degradation classes over the whole period. In order to adapt SVAT-CN to the chamber measurements, the parameters of leaf physiology and soil respiration have been set to values that accommodate the different vegetation types and cover of the plots (Appendix A, Table A2).

Daily sums of ecosystem respiration $\left(R_{\text {eco }}\right)$ over IM were overestimated by the model during period 1 , but underestimated during the second setup over IM (period 4); see Fig. 4. This might be attributable to a difference in leaf area index (LAI) between the rings for period 1 and period 4, as they differed in biomass content at the end of the measurement campaign (Ring P1, NEE chamber: $3.1 \mathrm{~g}$ and P4, NEE chamber: $4.5 \mathrm{~g}$ ). The model has been adapted to both periods with one parameter set in order to reflect average conditions. Overall, the model predicted a mean $R_{\text {eco }}$ of $2.37 \mathrm{~g} \mathrm{C} \mathrm{m}^{-2} \mathrm{~d}^{-1}$ for IM, whereas the mean of the chamber data yielded $2.31 \mathrm{~g} \mathrm{Cm}^{-2} \mathrm{~d}^{-1}$. For the chamber setup over bare soil (BS, period 2), $R_{\text {eco }}$ were, on average, represented well by the model (on average $0.77 \mathrm{~g} \mathrm{C} \mathrm{m}^{-2} \mathrm{~s}^{-1}$ ) as compared to the data average of $0.81 \mathrm{~g} \mathrm{C} \mathrm{m}^{-2} \mathrm{~d}^{-1}$. Similarly, for DM (period 3) modelled $\left(1.81 \mathrm{~g} \mathrm{C} \mathrm{m}^{-2} \mathrm{~d}^{-1}\right)$ and measured ( $1.69 \mathrm{~g} \mathrm{Cm}^{-2} \mathrm{~d}^{-1}$ ) average $R_{\text {eco }}$ compared well. Analogous patterns were found for daily sums of gross ecosystem exchange $\left(\mathrm{GEE}=\mathrm{NEE}-R_{\mathrm{eco}}\right)$ : under- and overestimations of the daily sums characterised the setups over IM (period 1 and 4), but were compensated to some extent when analysing period 1 and 4 together (modelled 


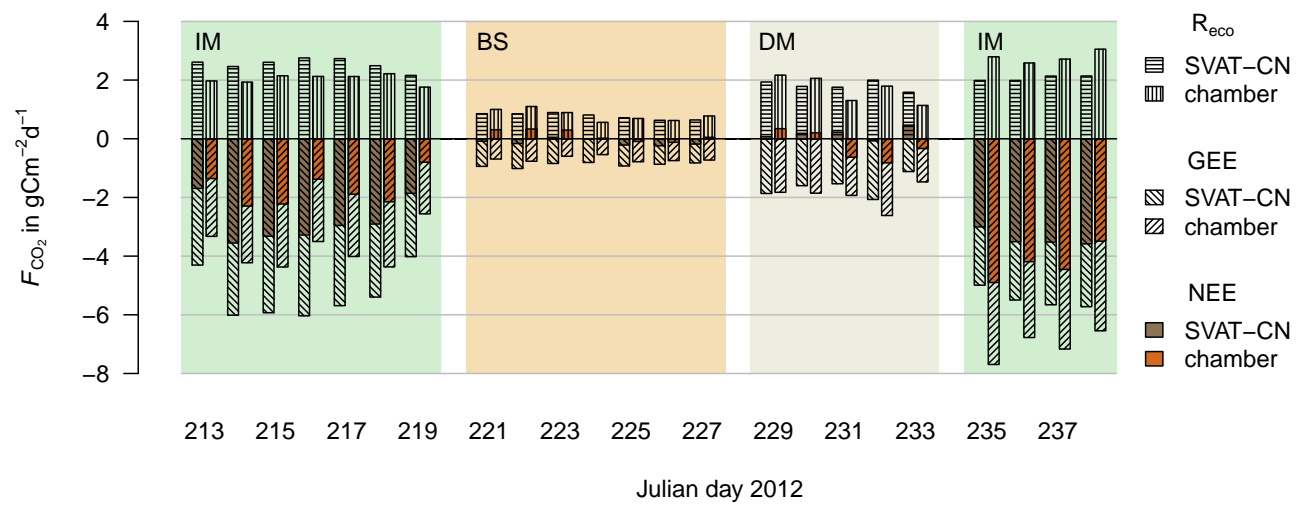

Figure 4. Comparison of measured and modelled daily carbon exchange sums from 31 July to 25 August 2012 at Kema. Hatched bars denote the simulated gross ecosystem exchange (GEE) and ecosystem respiration $\left(R_{\text {eco }}\right)$, the sum is the net ecosystem exchange (NEE, coloured bars). The four periods represent different stages of vegetation degradation (see Table 2). Leaf physiology and soil respiration was parameterised for best representation of the gas exchange chamber data over the entire time period (see Sect. 2.5.2). Missing dates indicate days when chambers were set up or relocated to another treatment.

average GEE $-5.39 \mathrm{~g} \mathrm{Cm}^{-2} \mathrm{~d}^{-1}$, measured average GEE $-4.96 \mathrm{~g} \mathrm{C} \mathrm{m}^{-2} \mathrm{~s}^{-1}$ ). Average modelled GEE over BS with $-0.89 \mathrm{~g} \mathrm{C} \mathrm{m}^{-2} \mathrm{~d}^{-1}$ compared well to measured GEE for period $2\left(-0.69 \mathrm{~g} \mathrm{C} \mathrm{m}^{-2} \mathrm{~d}^{-1}\right)$. Over DM, the average modelled GEE was $-1.64 \mathrm{~g} \mathrm{Cm}^{-2} \mathrm{~d}^{-1}$, and measured GEE showed an average of $-1.94 \mathrm{~g} \mathrm{Cm}^{-2} \mathrm{~d}^{-1}$. The model performance with respect to 30 min NEE is shown in Table 7, scatter plots of the regression are given in a supplement.

The mean carbon fluxes derived from SVAT-CN simulations for the different degradation classes over the vegetation period are shown in Fig. 5. A noticeable carbon uptake of $-2.89 \mathrm{~g} \mathrm{C} \mathrm{m}^{-2} \mathrm{~d}^{-1}$ for IM reduces to -0.09 for BS and even shifts to a weak release of 0.2 at DM. This is mainly related to a drop in GEE by $83 \%$ for BS and $64 \%$ for DM, compared to IM (100\%). While $R_{\text {eco }}$ for BS is reduced by $66 \%$, it only reduces by $12 \%$ for DM, leading to the small net release already mentioned.

Cumulative NEE was calculated applying the four different model setups previously described: IM; DM and BS stages of Kobresia pastures at Kema; and alpine steppe (AS) ecosystem at Nam Co (Fig. 6). The simulation period ranged from the period 12 July to 26 August 2012. For this period, only the IM stage showed significant carbon uptake of $-133 \mathrm{~g} \mathrm{C} \mathrm{m}^{-2}$. DM and BS ecosystems were more or less carbon neutral $\left(-4 \mathrm{~g} \mathrm{Cm}^{-2}\right.$ uptake at $\mathrm{BS}$, and $9 \mathrm{~g} \mathrm{Cm}^{-2}$ release at DM). The model for AS resulted in a carbon loss of $24 \mathrm{~g} \mathrm{C} \mathrm{m}^{-2}$ for the investigated period.

\subsection{Distribution of the assimilated carbon in Kobresia pastures and the soil}

The results from two ${ }^{13} \mathrm{CO}_{2}$ pulse labelling experiments at Xinghai 2009 (Hafner et al., 2012) and Kema 2010 (Ingrisch et al., 2014) show the distribution of assimilated carbon (C) in a montane and alpine Kobresia pasture (Fig. 7). The study in Xinghai showed that $\mathrm{C}$ translocation was different on plots where vegetation had changed from Cyperaceae to Poaceae dominance, induced by grazing cessation. Less assimilated C was stored in belowground pools. The study in Kema showed that roots within the turf layer act as the main sink for recently assimilated $\mathrm{C}(65 \%)$ and as the most dynamic part of the ecosystem in terms of $\mathrm{C}$ turnover. This is also the main difference between the experiments on the two sites as in the case of the alpine pasture (Kema) more $\mathrm{C}$ was allocated belowground than in montane pasture, where such a turf layer does not exist. However, as the experiments were conducted under different conditions and in consecutive years, a comparison of absolute values is not possible as the determined $\mathrm{C}$ fraction varies also throughout the growing season (Swinnen et al., 1994; Kuzyakov and Domanski, 2000).

At Kema, the ${ }^{13} \mathrm{CO}_{2}$ labelling was furthermore coupled with eddy-covariance measurements to determine the absolute values of the carbon distribution in the plants, roots and the soil following a method developed by Riederer (2014): The relative $\mathrm{C}$ distribution within the various pools of the ecosystem, at the end of the allocation period (i.e. when the ${ }^{13} \mathrm{C}$ fixing reaches a steady state, in our case 15 days after the labelling) was multiplied with a nearly steady-state daily carbon uptake measured with the eddy-covariance method. Besides the determination of absolute values, the continuous observation of the exchange regime with the EC confirms that the pulse labelling was conducted under atmospheric conditions similar to those of the whole allocation period. This leads to more representativeness of the result of the ${ }^{13} \mathrm{CO}_{2}$ labelling experiment, which could not be repeated due to the short vegetation period and restricted access to this remote area. Please note that repetitions have been carried out, leading to standard errors as depicted in Fig. 7. 


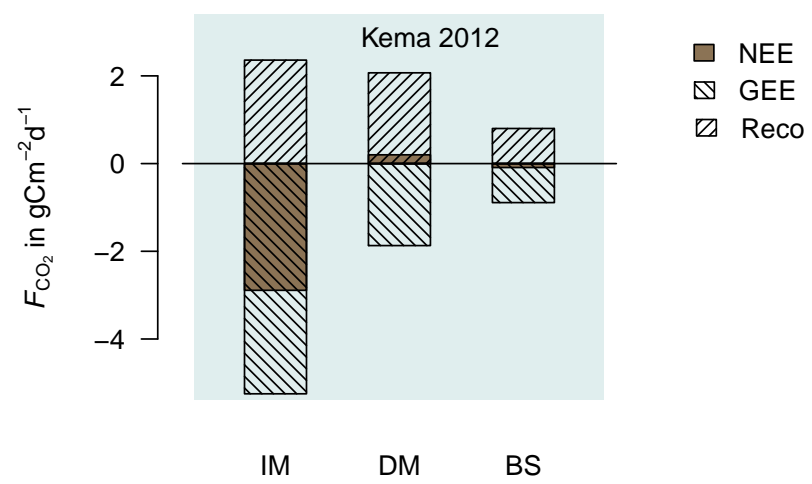

Figure 5. Simulated carbon fluxes at Kema in 2012 (46 days: 12 July to 26 August 2012) for IM, DM, and BS. Hatched bars denote the simulated GEE and $R_{\text {eco }}$, the sum is the NEE (brown bar).

\subsection{Influence of plant cover on convection and precipitation}

For investigating the influence of degradation on the development of convection and precipitation, the ATHAM model was applied for $25 \%$ (V25) and $75 \%$ (V75) plant cover at the Nam Co basin, with each of these in a dry and a wet scenario. From Fig. 8 it becomes immediately apparent that wet surface conditions are associated with higher deposited precipitation. At the same time, near-surface relative humidities are higher (not shown). For both the dry and wet cases an earlier cloud and convection development is observed for the less vegetated surface: simulations produce higher cloud cover and more convection from 10:00 local mean time (LMT) onward. At Nam Co we observed the frequent development of locally generated convective systems at similar hours in the field. Thus clouds block more incoming solar radiation between 10:00 and 14:00 LMT, the time with the potentially highest short-wave radiation forcing, for the less vegetated system compared to the intact vegetation scenario. Consequently, simulated surface temperatures were higher for the V75 scenario, leading to higher surface fluxes and a stronger simulated convection development over the day as a whole. A potential albedo effect can be excluded since the observed albedo of the vegetated surface is similar to that of the bare surface and surface temperatures remain virtually identical until convection develops.

The mechanism for this process is presumably that the vegetation cover reduces bare soil evaporation. At the same time, higher surface temperatures due to higher radiation input result in both larger sensible and latent heat fluxes in the afternoon hours, while the plant cover is able to access water that is not available for surface evaporation.

This hypothesis obviously needs to be investigated more thoroughly with field observations and simulations, but the findings indicate that changes in surface conditions can affect convective dynamics and local weather. This preliminary in-
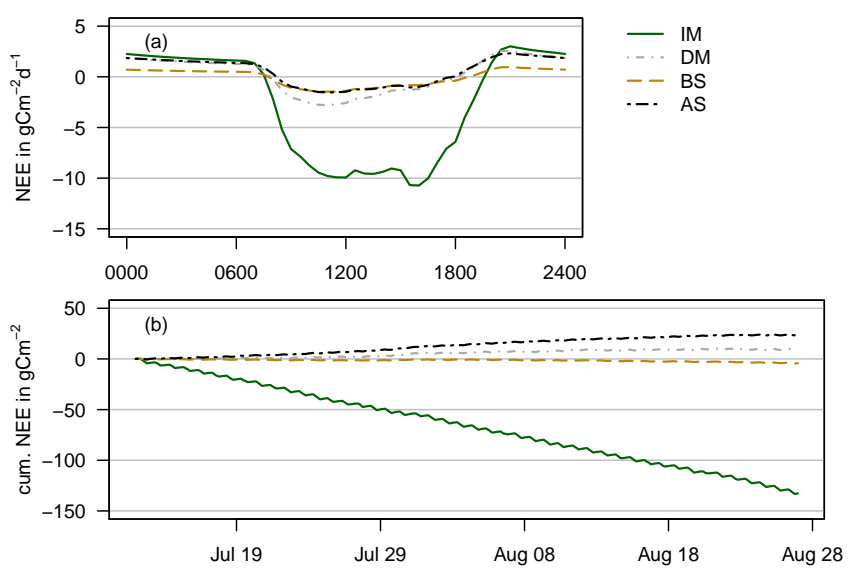

Figure 6. Model results of net ecosystem exchange (NEE) over 46 days of July and August 2012 at Kema. (a): mean diurnal cycle, and (b): cumulative NEE. The four lines represent different stages of vegetation degradation (IM, DM, BS, and AS).

vestigation of vegetation-atmosphere feedbacks did not take into account any spatial patterns in surface degradation that may result in larger patches with different surface conditions that may then affect circulation. However, such circulation effects are typically found in modelling studies using patch sizes with length scales that are several times the boundarylayer height.

\subsection{Simulation of different degradation states}

The results for the different degradation states allow the simulation of the NEE and evapotranspiration for a gradual change from IM to BS using a tile approach of the fluxes (Avissar and Pielke, 1989). Such a tile approach is exemplarily shown for different percentages of the ecosystem types IM and BS for a 46 days period in July and August 2012 at Kema site, with simulated NEE (Fig. 9a) and evapotranspiration (Fig. 9b). As expected from the cumulative carbon gains for $S_{\mathrm{IM}}$ and $S_{\mathrm{BS}}$ shown in Fig. 5, $S_{\mathrm{IM}}$ developed the largest carbon sink over the investigated summer period, whereas $S_{\mathrm{BS}}$ is nearly carbon neutral in summer and a source for longer periods. The intermediate stages showed decreasing average carbon uptake with increasing amount of bare soil. Diurnal variability is largest for $100 \% S_{\mathrm{IM}}$ and smallest for $100 \% S_{\mathrm{BS}}$ in the ecosystem, as indicated by the interquartile ranges in the box plot.

Evapotranspiration decreases from $S_{\mathrm{IM}}$ to $S_{\mathrm{BS}}$ in this model degradation experiment (Fig. 9b), but this reduction is small compared to the overall day-to-day variability and is not supported by the lysimeter measurements (Fig. 3). Therefore a change in mean ET due to degradation cannot be confirmed in this study. The day-to-day variability, however, increases from $S_{\mathrm{IM}}$ to $S_{\mathrm{BS}}$. This is connected to a larger variability of simulated soil moisture in the uppermost layer, as the turf layer retains more water due to its higher field 

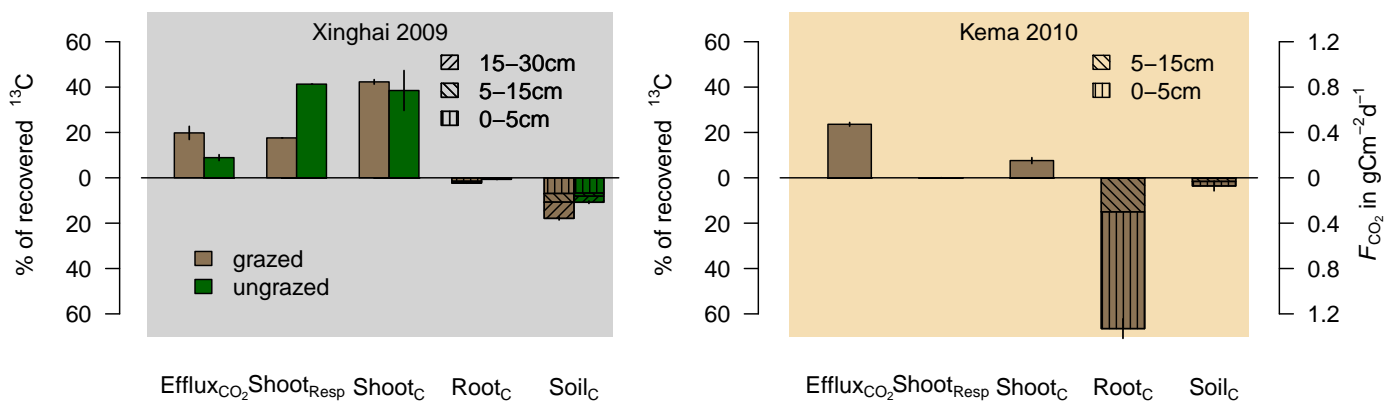

Figure 7. ${ }^{13} \mathrm{C}$ partitioning and distribution of recently allocated $\mathrm{C}$ within the various pools, namely $\mathrm{CO}_{2}$ efflux, shoot respiration, shoots, roots and soil for Xinghai site (grazed and ungrazed) in 2009 and Kema site (IM) in 2010, determined at the end of a 29 day and 15 day allocation period, respectively. Vertical lines in the bars denote standard errors $(n=3$ for Xinghai 2009 and $n=8$ for Kema 2010). Total fluxes of $\mathrm{C}$ in $\mathrm{g} \mathrm{C} \mathrm{m}^{-2} \mathrm{~d}^{-1}$ to the different $\mathrm{C}$ pools at Kema site are based on the combination of eddy-covariance measurements and labelling. Shoot respiration is not measured, but determined as difference between the ${ }^{13} \mathrm{C}$ recovery at the first sampling and the sampling at the end of the allocation period. First sampling in Xinghai was 1 day after the labelling and in Kema at the labelling day. Figure modified after Hafner et al. (2012) and Ingrisch et al. (2014).
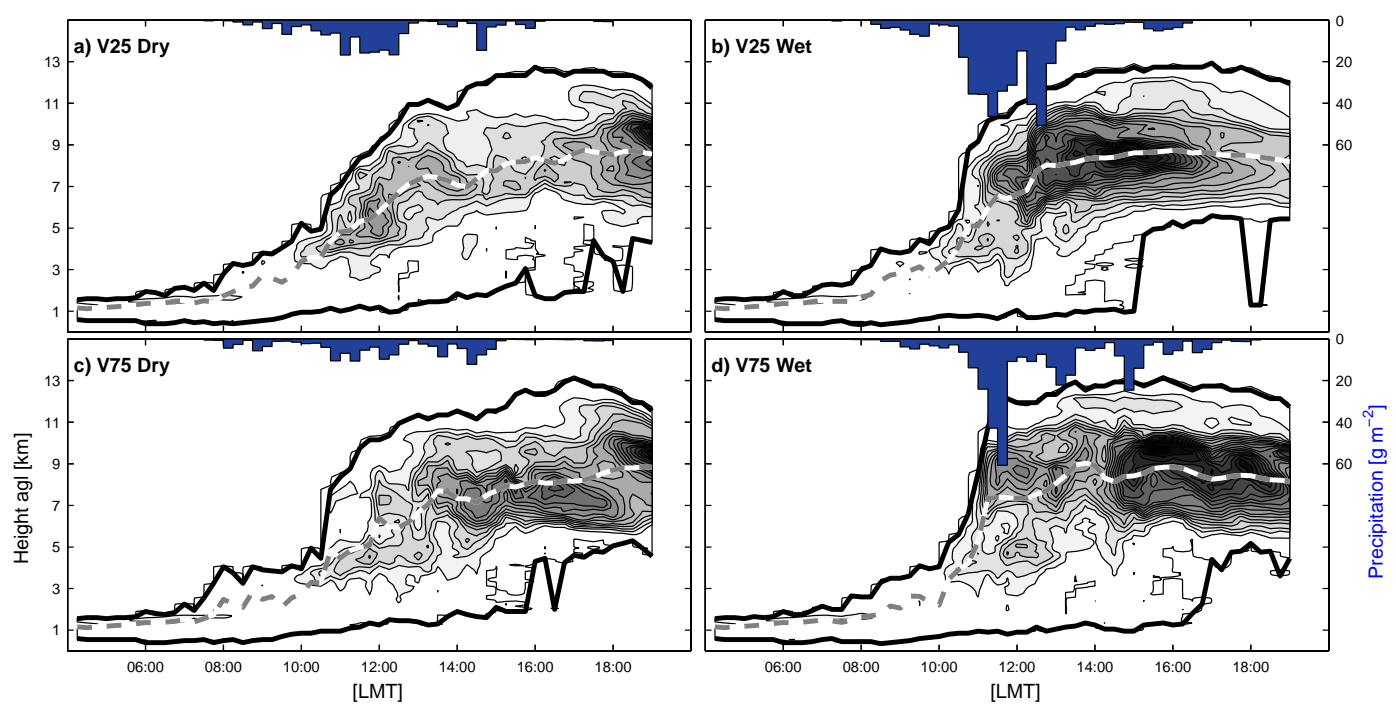

Figure 8. Simulated convection development and deposited precipitation (blue bars) for a symmetric Tibetan Valley with $150 \mathrm{~km}$ width. The black lines indicate cloud base and cloud top in kilometres above ground level; the dashed line shows the centre of the cloud mass and the contours give the mean cloud water and ice concentration integrated over the model domain. V25 and V75 refer to $25 \%$ and $75 \%$ vegetation cover, while wet and dry indicate initial soil moisture corresponding to 1.0 and $0.5 \times$ field capacity, respectively. Times are given in local mean time (LMT), which is two hours before Beijing standard time (CST).

capacity and lower soil hydraulic conductivity, and the roots can extract water for transpiration from lower soil layers as well.

\section{Conclusions}

Increasing degradation of the Kobresia pygmaea turf significantly reduces the carbon uptake and the function of Kobresia pastures as a carbon sink, while the influence on the evapotranspiration is less dominant. However, the shift from transpiration to evaporation was found to have a significant influence on the starting time of convection and cloud and pre- cipitation generation: convection above a degraded surface occurs before noon instead of after noon. Due to the dominant direct solar radiation on the Tibetan Plateau, the earlygenerated cloud cover reduces the energy input and therefore the surface temperatures. Therefore the degradation state of the Kobresia pastures has a significant influence on the water and carbon cycle and, in consequence, on the climate system. Due to the relevance of the Tibetan Plateau on the global circulation changes, the surface properties on the highland have influences on larger scales. These changes in the water and carbon cycle are furthermore influenced by global warming 

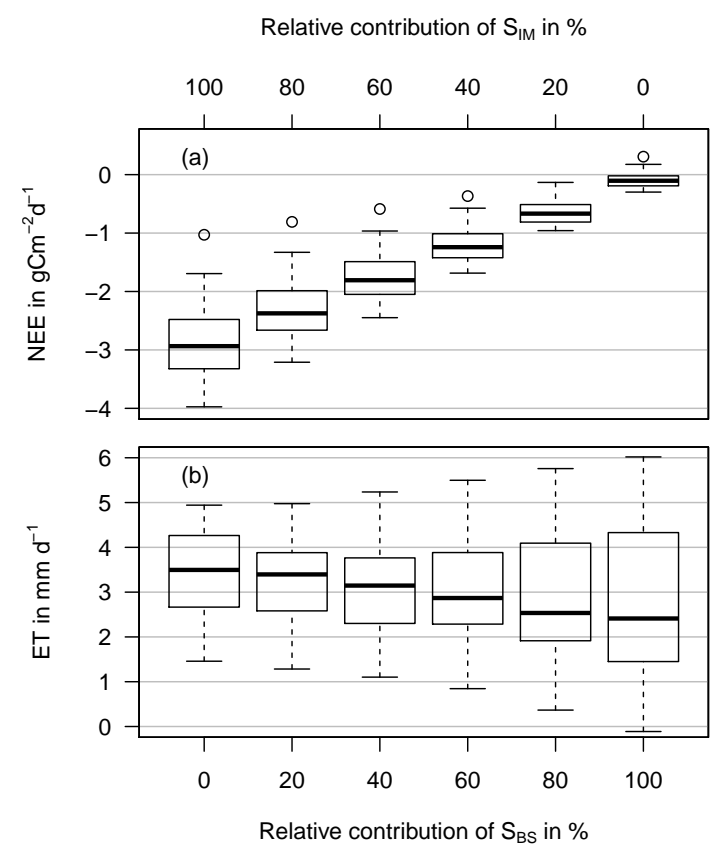

Figure 9. Modelled daily net ecosystem exchange (top, NEE) and modelled daily evapotranspiration (bottom, ET) for 46 days (12 July to 26 August 2012) at Kema (varying combination of $S_{\mathrm{IM}}$ and $S_{\mathrm{BS}}$ ): box plot with median, $25 \%$ and $75 \%$ quartiles; bars represent quartiles \pm 1.5 times interquartile range.

and an extended growing season (Che et al., 2014; Shen et al., 2014; Zhang et al., 2014).

Plot scale experiments are a promising mechanistic tool for investigating processes that are relevant for larger scales. Since all results showed a high correlation between modelled and experimental data, a combination is possible with a tile approach with flux averaging to realise model studies that consider gradual degradation schemata. The consequent combination of plot scale, ecosystem scale and landscape scale shows the importance of the integration of experimental and modelling approaches.

The palaeo-environmental reconstruction (Miehe et al., 2014) as well as the simulations of the present study suggest that the present grazing lawns of Kobresia pygmaea are a synanthropic ecosystem that developed through long-lasting selective free-range grazing of livestock. This traditional and obviously sustainable rangeland management would be the best way to conserve and possibly increase the carbon stocks in the turf and its functions. Otherwise, an overgrazing connected with erosion would destroy the carbon sink. Considering the large area, even the loss of this small sink would have an influence on the climate relevant carbon balance of China.
From our investigation we propose the need for the following additional research:

- Extension of this integrated experimental-modelling research scheme to the full annual cycle. This cannot done by a single campaign but is possible within the Third Pole initiative (Yao et al., 2012). The modelling studies of this paper make such investigations realistic.

- The results obtained so far on just these three sites should be extended to an increased number of experimental sites, supported by appropriate remote sensing tools, in order to regionalise degradation patterns and related processes. The methodical and data basis is available for this (Ma et al., 2008, 2011, 2014; Yang et al., 2013)

- Investigation of the processes along elevation gradients, with special reference to functional dependences. Therefore biological data (Miehe et al., 2014) as well as atmospheric data (Ma et al., 2008) should be combined.

- The use of remote sensing cloud cover studies to evaluate simulations of cloud generation and precipitation depending on surface structures. This should be combined with high resolution WRF modelling studies, which are already available for the Tibetan Plateau (Maussion et al., 2014). 


\section{Appendix A: Model adaption to the Tibetan Plateau}

\section{A1 Adaption of SEWAB}

Considering the specific problems on the Tibetan Plateau, three changes have been implemented in SEWAB. Those are a variable thermal roughness length (Yang et al., 2008), soil thermal conductivity calculation (Yang et al., 2005) and the parameterisation of bare soil evaporation (Mihailovic et al., 1993). These changes have been already applied and evaluated at the alpine steppe site Nam Co using the same data set (Gerken et al., 2012; Biermann et al., 2014).

Furthermore, all relevant model parameters have been adapted to the site-specific conditions (see Table A1). The parameters for the alpine steppe site Nam Co have been used as published in Biermann et al. (2014), which were inferred from field and laboratory measurements. Specific parameters for the Kema site have been elaborated as follows: albedo has been estimated from radiation measurements individually for the 2010 and 2012 data set. The fraction of vegetated area has been surveyed (Sect. 2.2), root depth is assessed from soil profiles (Biermann et al., 2011, 2013) and the roughness length for momentum is estimated from eddy-covariance friction velocity under neutral conditions. The LAI for the vegetated area has been calculated from a biomass survey (September 2012, $n=5$ ) and subsequent scans of leaf surface using WinSeedle. Maximum stomatal conductance has been elaborated by gas exchange measurements with $\mathrm{Ko}$ bresia pygmaea in Göttingen (see Appendix B2), which has been translated to minimum stomatal resistance.

Soil properties have been estimated from measurements separately for conditions with root mat (RM: IM and DM) and without root mat (BS). As SEWAB accepts only one soil parameter set for the whole soil column, the properties of the uppermost $5 \mathrm{~cm}$ have been used. The bulk density has been surveyed in 2012 for soil layers of $5 \mathrm{~cm}$ thickness, down to $30 \mathrm{~cm}$ for RM and $14 \mathrm{~cm}$ for BS $(n=4$ plots $\times 4$ replicates $=16$ for each layer). Average soil organic carbon content of the turf layer was $9 \%$, measured by dry combustion (Vario EL, Elementar, Hanau), corresponding to approximately $18 \%$ organic matter, which is in agreement with previous analyses by Kaiser et al. (2008). This amount has been distributed to three layers of $5 \mathrm{~cm}$ according to the relative content of root mass in each layer, sampled in 2010 $(n=4$ plots $\times 3$ replicates $=12$ for each layer $)$. From bulk density and mass fraction of organic matter the porosity in $0-5 \mathrm{~cm}$ depth is estimated with $0.593 \mathrm{~m}^{3} \mathrm{~m}^{-3}$, assuming densities of $2.65 \mathrm{~g} \mathrm{~m}^{-3}$ for mineral content and $1.2 \mathrm{~g} \mathrm{~m}^{-3}$ for organic content. The soil heat capacity of solid matter is combined from $2.1 \times 10^{6} \mathrm{~J} \mathrm{~m}^{-3} \mathrm{~K}^{-1}$ for mineral content and $2.5 \times 10^{6} \mathrm{~J} \mathrm{~m}^{-3} \mathrm{~K}^{-1}$ for organic matter according to Hillel (1980). Thermal conductivities for dry soil and at saturation, needed for the conductivity calculation (Yang et al., 2005), have been investigated for a similar turf layer (Chen et al., 2012: Anduo site for RM, BJ site for BS). Further, we de- rived saturated hydraulic conductivities of $1.9 \times 10^{-5} \mathrm{~m} \mathrm{~s}^{-1}$ and $4.6 \times 10^{-5} \mathrm{~m} \mathrm{~s}^{-1}$ as mean values for RM and BS, respectively, using infiltrometer measurements from 2010 (Biermann et al., 2011, 2013). An in situ soil water retention curve was established from tensiometer and TDR profile measurements in 2012, reflecting the properties of RM in the first $15 \mathrm{~cm}$ and the properties of BS in $25 \mathrm{~cm}$ depth. From this data the matrix potential at saturation $\Psi_{\text {sat }}$ and the exponent $b$ for the relationship by Clapp and Hornberger (1978) is estimated via linear regression of the logarithmic form: $\log \left(\Psi_{\Theta}\right)=\log \left(\Psi_{\text {sat }}\right)+b \cdot \log \left(\frac{\Theta_{\text {sat }}}{\Theta}\right)$. Further, the soil water content at field capacity and wilting point has been derived from this relationship assuming $\mathrm{pF}$ values $\left(=\log \left(\Psi_{\Theta}\right)\right)$ of $2.5 \log (\mathrm{hPa})$ and $4.5 \log (\mathrm{hPa})$ for $\Theta_{\mathrm{FC}}$ and $\Theta_{\mathrm{WP}}$, respectively.

\section{A2 Adaption of SVAT-CN}

\section{Species parameterisation of the leaf model for Kobresia pygmaea:}

Measurements of in situ $\mathrm{CO}_{2}$ and $\mathrm{H}_{2} \mathrm{O}$ leaf gas exchange in response to temperature, radiation, $\mathrm{CO}_{2}$ mixing ratio, and relative humidity were made using a portable gas exchange system (WALZ GFS3000, Walz, Effeltrich/Germany). Single factor dependencies of leaf gas exchange to light, temperature, $\mathrm{CO}_{2}$ mixing ratio, and relative humidity, were performed for copiously watered Kobresia pygmaea plants from greenhouse experiments at the University of Göttingen. The respective plant individuals have been collected in 2012 at the Kema site with underlying soil monoliths, and regrown/recovered in Göttingen. The measurement setup was situated in a greenhouse chamber regulated to $15^{\circ} \mathrm{C}$. GFS3000 gas exchange measurements were performed at six different temperatures $\left(7.5,10,15,20,25\right.$, and $\left.30^{\circ} \mathrm{C}\right)$ inside the cuvette and a series of different relative humidities of the inlet air, ranging between 20 and $65 \%$, matching meteorological conditions found at the field site during the intensive campaign in 2010. As high humidity inside the chamber system leads to problems with water condensation in the tubes, the conditions were restricted to relative humidity up to $65 \%$. Data have been analysed using the physiology-based leaf gas exchange model (Farquhar et al., 1980; Ball et al., 1987) to derive estimates for those parameters that describe the carboxylase kinetics, electron transport, respiration and stomatal function. We used a non-linear least trimmed squares regression tool (Reth et al., 2005c), that minimises the sum of squared residuals excluding the largest $5 \%$ of residuals, assumed to indicate data contamination or data-model inconsistencies. Sets of parameter values for Kobresia pygmaea (Appendix, Table A2) were obtained as the basis for calculating canopy flux rates at the different field sites. 
Table A1. Relevant parameters to describe the surface characteristic in SEWAB and SVAT-CN. Kema represents two parameter sets: (i) root mat (RM) for IM and DM; and (ii) BS.

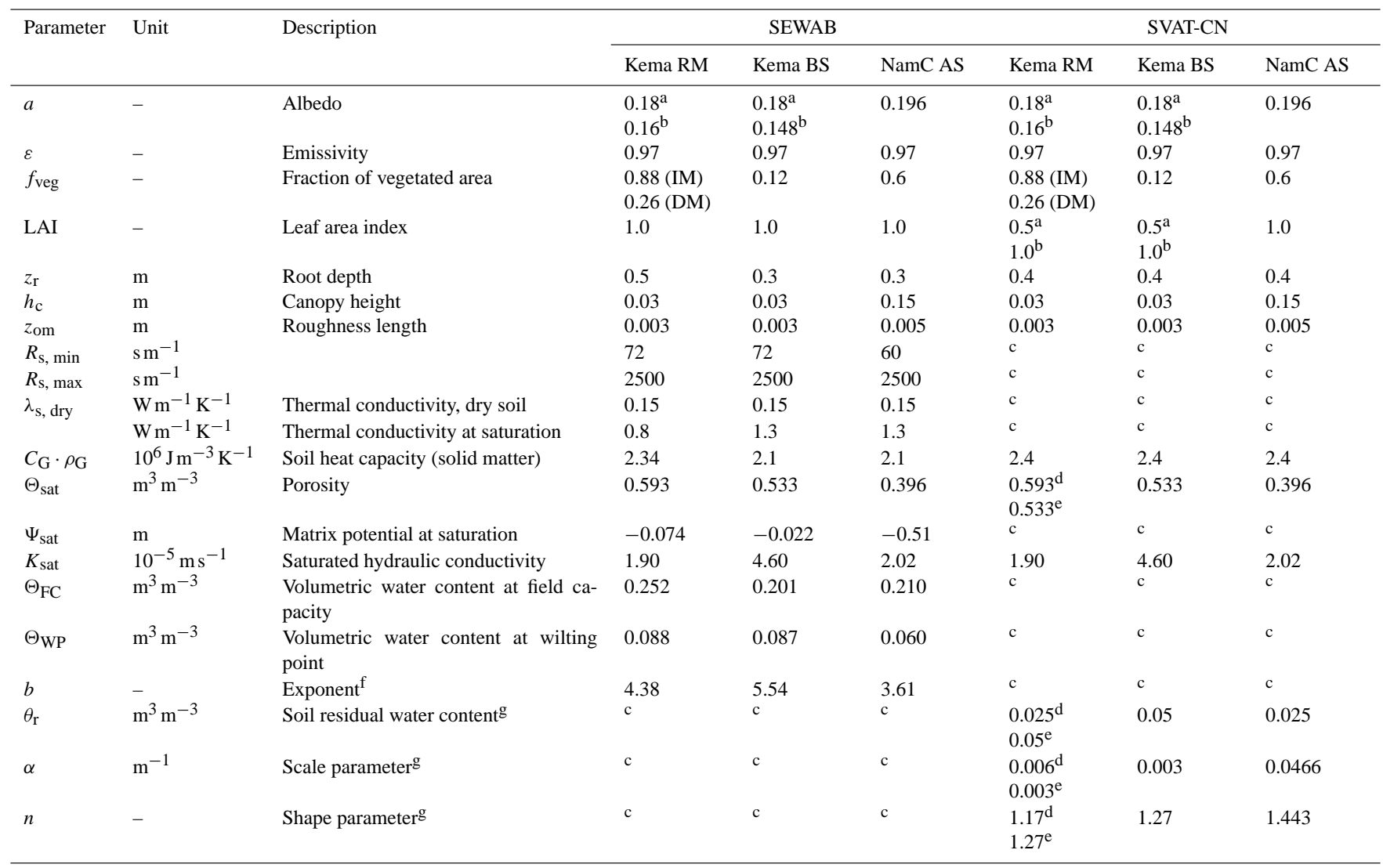

${ }^{\mathrm{a}}$ From measurements in $2010{ }^{\mathrm{b}}$ from measurements in $2012 ;^{\mathrm{c}}$ parameter not available due to different parameterisation; ${ }^{\mathrm{d}}$ organic layer $\left(0-15 \mathrm{~cm}\right.$ depth); ${ }^{\mathrm{e}}$ mineral layer $\left(15+\mathrm{cm}\right.$ depth); ${ }^{\mathrm{f}}$ exponent $b$ for relationships after Clapp and Hornberger (1978); ${ }^{\mathrm{g}}$ parameter according to van Genuchten (1980).

\section{Parameterisation of soil retention curve:}

In SVAT-CN the relationship between soil matrix potential $\Psi$ (or better water suction, in units of $\mathrm{m}$ ) and soil water content $\theta\left(\mathrm{m}^{3} \mathrm{~m}^{-3}\right)$ is described by a retention curve after van Genuchten (1980)

$\Psi(\theta)=\frac{1}{\alpha} \cdot\left[\left(\frac{\theta-\theta_{\mathrm{r}}}{\theta_{\mathrm{s}}-\theta_{\mathrm{r}}}\right)^{-\frac{1}{m}}-1\right]^{\frac{1}{n}}$,

where $\theta$ is soil water content $\left(\mathrm{m}^{3} \mathrm{~m}^{-3}\right), \theta_{\mathrm{r}}$ soil residual water content $\left(\mathrm{m}^{3} \mathrm{~m}^{-3}\right), \theta_{\mathrm{s}}$ soil saturated water content $\left(\mathrm{m}^{3} \mathrm{~m}^{-3}\right), \alpha$ a scale parameter $\left(\mathrm{m}^{-1}\right)$, and $n$ and $m$ shape parameters, with $m=1-1 / n$. Site-specific data of measured retention curves (soil moisture and soil water potential from AWS, Table 3) have been used to parameterise $\theta_{\mathrm{r}}, \alpha$, and $n$ (Appendix, Table A1) by non-linear least square regression.

\section{Parameterisation of soil respiration:}

Soil respiration $\left(R_{\mathrm{s}}, \mu \mathrm{mol} \mathrm{m}{ }^{-2} \mathrm{~s}^{-1}\right)$ is modelled as a function of modelled soil temperature $T_{\mathrm{S}}(\mathrm{K})$ and soil water content $\theta$ $\left(\mathrm{m}^{3} \mathrm{~m}^{-3}\right)$ in $10 \mathrm{~cm}$ depth as follows:

$$
\begin{aligned}
& R_{\mathrm{S}}=R_{\text {norm }} \cdot e^{\left(E_{0} \cdot \frac{1}{T_{\mathrm{ref}}-T_{0}} \cdot \frac{1}{T_{\mathrm{s}}-T_{0}}\right)} \\
& \cdot \max \left(0.01, \frac{\theta-\theta_{0}}{\left(\theta_{\text {half }}-\theta_{0}\right)+\left(\theta-\theta_{0}\right)}\right)
\end{aligned}
$$

where $R_{\text {norm }}$ is the base rate at optimum soil water content and reference temperature $\left(\mu \mathrm{mol} \mathrm{m}{ }^{-2} \mathrm{~s}^{-1}\right) ; E$ an activation energy parameter $\left({ }^{\circ} \mathrm{C}\right)$ that determines temperature sensitiv-

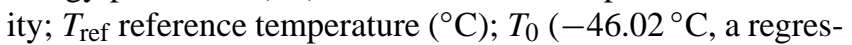
sion parameter from Lloyd and Taylor, 1994), $\theta$ the soil water content where the rate is reduced to zero $\left(\mathrm{m}^{3} \mathrm{~m}^{-3}\right)$, and $\theta_{\text {half }}$ the soil water content where the rate is reduced by half $\left(\mathrm{m}^{3} \mathrm{~m}^{-3}\right)$.

The original formulation in SVAT-CN was changed to accommodate the much higher soil organic content in the Kobresia ecosystems. $T_{\text {ref }}$ and $E$ were adapted to match soil respiration data measured with gas exchange chambers. For Kema a $T_{\text {ref }}$ of $16^{\circ} \mathrm{C}$ for the "Kobresia", and $24^{\circ} \mathrm{C}$ for the "bare soil" plots, were used. At Nam Co $T_{\text {ref }}$ was set to $16^{\circ} \mathrm{C}$. For all sites an $E$ of $500{ }^{\circ} \mathrm{C}$ was employed. $R_{\text {norm }}$ was $2.3 \mu \mathrm{mol} \mathrm{m}{ }^{-2} \mathrm{~s}^{-1}$. At all sites only weak dependences on soil 
Table A2. Parameters applied to describe leaf physiology of Kobresia pygmaea. For detailed explanation of the leaf model and use of the parameters see Falge (1997) and Falge et al. (2003). The equations are also available in Wohlfahrt et al. (1998). Output of the model is on a projected leaf area basis.

\begin{tabular}{|c|c|c|c|c|c|}
\hline Description & Parameter & $\begin{array}{c}\text { Value } \\
\text { original }\end{array}$ & $\begin{array}{l}\text { Value } \\
\text { Kema }\end{array}$ & $\begin{array}{c}\text { Value } \\
\text { NamCo }\end{array}$ & Unit \\
\hline $\begin{array}{l}\text { Dark } \\
\text { respiration }\end{array}$ & $\begin{array}{l}F\left(R_{\mathrm{d}}\right) \\
E_{\mathrm{a}}\left(R_{\mathrm{d}}\right)\end{array}$ & $\begin{array}{c}1.51 \\
72561\end{array}$ & 2.42 & 1.51 & $\begin{array}{l}\mu \mathrm{mol} \mathrm{m}^{-2} \mathrm{~s}^{-1} \\
\mathrm{~J} \mathrm{~mol}^{-1}\end{array}$ \\
\hline $\begin{array}{l}\text { Electron } \\
\text { transport } \\
\text { capacity }\end{array}$ & $\begin{array}{l}c\left(P_{\mathrm{ml}}\right) \\
\Delta H_{\mathrm{a}}\left(P_{\mathrm{ml}}\right) \\
\Delta H_{\mathrm{d}}\left(P_{\mathrm{ml}}\right) \\
\Delta S\left(P_{\mathrm{ml}}\right)\end{array}$ & $\begin{array}{c}61.93 \\
50224 \\
200000 \\
436.8\end{array}$ & 99.1 & 28.0 & $\begin{array}{l}\mu \mathrm{mol} \mathrm{m}^{-2} \mathrm{~s}^{-1} \\
\mathrm{~J} \mathrm{~mol}^{-1} \\
\mathrm{~J} \mathrm{~mol}^{-1} \\
\mathrm{JK}^{-1} \mathrm{~mol}^{-1}\end{array}$ \\
\hline $\begin{array}{l}\text { Carboxylase } \\
\text { capacity }\end{array}$ & $\begin{array}{l}c\left(V c_{\max }\right) \\
\Delta H_{\mathrm{a}}\left(V c_{\max }\right) \\
\Delta H_{\mathrm{d}}\left(V c_{\max }\right) \\
\Delta S\left(V c_{\max }\right)\end{array}$ & $\begin{array}{c}53.4 \\
41953 \\
200000 \\
206.1\end{array}$ & 85.4 & 32.5 & $\begin{array}{l}\mu \mathrm{mol} \mathrm{m}^{-2} \mathrm{~s}^{-1} \\
\mathrm{~J} \mathrm{~mol}^{-1} \\
\mathrm{~J} \mathrm{~mol}^{-1} \\
\mathrm{JK}^{-1} \mathrm{~mol}^{-1}\end{array}$ \\
\hline $\begin{array}{l}\text { Carboxylase } \\
\text { kinetics }\end{array}$ & $\begin{array}{l}f\left(K_{\mathrm{c}}\right) \\
E_{\mathrm{a}}\left(K_{\mathrm{c}}\right) \\
f\left(K_{\mathrm{o}}\right) \\
E_{\mathrm{a}}\left(K_{\mathrm{o}}\right) \\
f(\tau) \\
E_{\mathrm{a}}(\tau)\end{array}$ & $\begin{array}{c}299.469 \\
65000 \\
159.597 \\
36000 \\
2339.53 \\
-28990\end{array}$ & & & $\begin{array}{l}\mu \mathrm{mol} \mathrm{mol}^{-1} \\
\mathrm{~J} \mathrm{~mol}^{-1} \\
\mathrm{mmol} \mathrm{mol}^{-1} \\
\mathrm{~J} \mathrm{~mol}^{-1} \\
- \\
\mathrm{J} \mathrm{mol}^{-1}\end{array}$ \\
\hline $\begin{array}{l}\text { Light use } \\
\text { efficiency }\end{array}$ & $\alpha$ & 0.0332 & 0.0332 & 0.0111 & $\begin{array}{l}(\mathrm{mol} \mathrm{CO} 2) \\
(\text { mol photons })^{-1}\end{array}$ \\
\hline $\begin{array}{l}\text { Stomatal } \\
\text { conductance }\end{array}$ & $\begin{array}{l}g_{\min } \\
\operatorname{gfac}_{0}\end{array}$ & $\begin{array}{c}18.7 \\
21\end{array}$ & & & $\begin{array}{l}\mathrm{mmolm}^{-2} \mathrm{~s}^{-1} \\
-\end{array}$ \\
\hline
\end{tabular}

For the Kema site, the respective formulation was adapted to: $\operatorname{gfac}=\max \left(15, \operatorname{gfac}_{0} \times 10^{(0.025 \cdot \Psi)}\right), \Psi$ in $\mathrm{MPa}$, simulated in $10 \mathrm{~cm}$ depth.

water content were implemented, with $\theta$ set to $\theta_{\mathrm{r}}$ of the retention parameterisations, and $\theta_{\text {half }}$ set to $0.035 \mathrm{~m}^{3} \mathrm{~m}^{-3}$.

\section{Parameterisation of leaf gas exchange:}

Species-specific parameters (Table A2) for the physiologybased leaf gas exchange model have been derived from $\mathrm{CO}_{2}$ and $\mathrm{H}_{2} \mathrm{O}$ leaf gas exchange measurements in the greenhouse (see "Species-specific parameterisation of the leaf model for Kobresia pygmaea" in this section). For the simulation of the Kema campaign in 2012, at first the original parameters of Table A2 were used for the vegetated area of the different degradation states of "Kobresia" (IM and DM) and "bare soil" plots, but underestimated the measured chamber gas exchange data. Consequently, three scaling parameters $c\left(P_{\mathrm{ml}}\right)$, $c\left(V c_{\max }\right)$, and $F\left(R_{\mathrm{d}}\right)$ were increased to $160 \%$ of the original values (Appendix, Table A2) for better comparison with measured data. The same parameters were used for the Kema 2010 campaign. The slope of the linear equation, which links stomatal conductance to assimilation and environmental controls, is modelled depending on soil matrix potential $(\Psi)$ in the main root layer: $\operatorname{gfac}=\max \left(15, \operatorname{gfac}_{0} \times 10^{(0.025 \cdot \Psi)}\right), \Psi$ in
$\mathrm{MPa}$, simulated in $10 \mathrm{~cm}$ depth. For the campaign in $2010-$ a year with drought stress effects, the respective formulation was adapted to $\operatorname{gfac}=\max \left(5, \operatorname{gfac}_{0} \times 10^{(0.1 \cdot \Psi)}\right)$.

For the Nam Co site, which is characterised by a vegetation composition of alpine steppe species different from the Kobresia pastures, no specific leaf gas exchange parameters are available. As a first attempt, leaf parameter sets of $\mathrm{Ko}$ bresia were applied, but these overestimated measured eddycovariance fluxes. Consecutive reduction of scaling parameters (Appendix, Table A2) yielded a better representation of the measured eddy-covariance fluxes. 


\section{Appendix B: Model evaluation}

\section{B1 Evapotranspiration: EC - SEWAB}

In order to test the performance of simulations of evapotranspiration with SEWAB, we compared the model results for Kema with the eddy-covariance measurements from 2010. Therefore the simulations for IM, DM and BS have been aggregated as weighted sums according to the eddy-covariance footprint ( $S_{\text {RefEC }}$, see Table 6$)$ and the measurements have been corrected according to the energy balance closure gap (Sect. 2.3.1). The results show that SEWAB simulations represent the measured evapotranspiration well (Fig. B1). Similarly, the simulations generally capture the diurnal cycle of evapotranspiration (Fig. B2), with median fluxes of approximately $6.5 \mathrm{~mm} \mathrm{~d}^{-1}$ at noon, and a large day-to-day variation caused by variable moisture conditions within the observation period in 2010. The simulations slightly overestimate daytime fluxes and underestimate night-time fluxes, the overall bias with high quality flux data (flag 1-3 out of a scheme ranging from 1-9, Foken et al., 2004) is $-0.13 \mathrm{mmd}^{-1}$.

\section{B2 Carbon flux: EC - SVAT-CN}

\section{Kema 2010:}

For best representation of the eddy-covariance data footprint, model results $\left(S_{\text {RefEC }}\right.$, Table 6$)$ are calculated as weighed sums of IM, DM and BS according to the proportion of total surface area in Table 2. Due to drier conditions in 2010, the vegetation was partially considered to be photosynthetically inactive, therefore the LAI of vegetated area has been reduced from 1 to 0.5 . Mean diurnal patterns of both, measured and modelled net ecosystem exchange showed $\mathrm{CO}_{2}$ release during night, and uptake during daytime hours, with a pronounced peak in the late morning hours, and a smaller peak in the late afternoon (Fig. B3). However, measured hourly medians of net ecosystem exchange ranged between -2.8 and $1.5 \mathrm{~g} \mathrm{C} \mathrm{m}^{-2} \mathrm{~d}^{-1}$ over the course of the day, whereas modelled medians reached a minimum of -3.0 and a maximum of $1.7 \mathrm{~g} \mathrm{C} \mathrm{m}^{-2} \mathrm{~d}^{-1}$. Although the model overestimated the $\mathrm{CO}_{2}$ uptake, especially in the midday hours, the comparison between hourly medians of model output and measured NEE (Fig. B4, left) showed that the simulations were generally realistic.

\section{Nam Co 2009 (AS):}

Compared to Kema data, mean diurnal patterns of measured and modelled net ecosystem exchange showed much smaller variation within a given hour (smaller interquartile ranges), and lower $\mathrm{CO}_{2}$ release during night, and lower uptake during daytime hours (lower diurnal amplitudes, see Fig. B5). As leaf physiological parameters were adapted to match measurements and model results, the ranges of both measured and modelled medians showed a better overlap: mea-

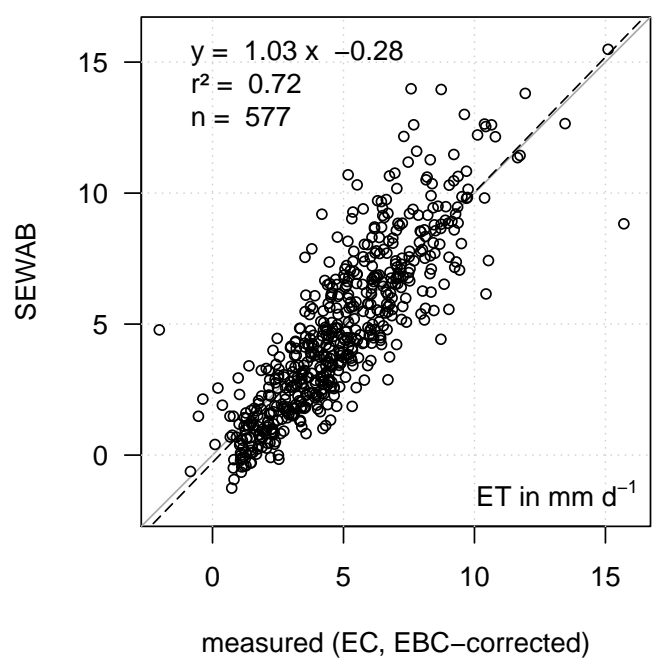

Figure B1. Scatter plot of measured vs. SEWAB modelled $S_{\text {RefEC }}$ evapotranspiration (ET) over 61 days of 2010 (3 June to 2 August) at Kema. Measured and modelled values are restricted to high data quality (flag 1-3 out of a scheme ranging from 1 to 9, Foken et al., 2004). Measured EC data is corrected according to the surface energy imbalance with the buoyancy flux correction.

sured hourly medians of net ecosystem exchange ranged between -2.3 and $1.0 \mathrm{~g} \mathrm{C} \mathrm{m}^{-2} \mathrm{~d}^{-1}$ over the course of the day, and modelled medians between -2.7 and $1.0 \mathrm{~g} \mathrm{Cm}^{-2} \mathrm{~d}^{-1}$. The wide range of measured NEE from $-6 \mathrm{~g} \mathrm{Cm}^{-2} \mathrm{~d}^{-1}$ to $1 \mathrm{~g} \mathrm{C} \mathrm{m}^{-2} \mathrm{~d}^{-1}$ at mid-day results from variable moisture conditions during the monsoon season and is consistent with chamber-based observations at a similar spot near Nam Co station (Hu et al., 2013).

At Nam Co the model overestimated the $\mathrm{CO}_{2}$ uptake especially in the afternoon hours, indicating a larger influence of soil respiration than currently represented by the model. Simulated soil respiration depends on simulated driving variables (soil temperature and moisture) and parameters. The latter have not been measured at Nam Co directly; instead the values from the Kema field site have been employed, eventually introducing the observed bias. Nevertheless, the correlation with $r^{2}$ of 0.90 between hourly medians of modelled and measured NEE (Fig. B4, right) was better than at Kema. 

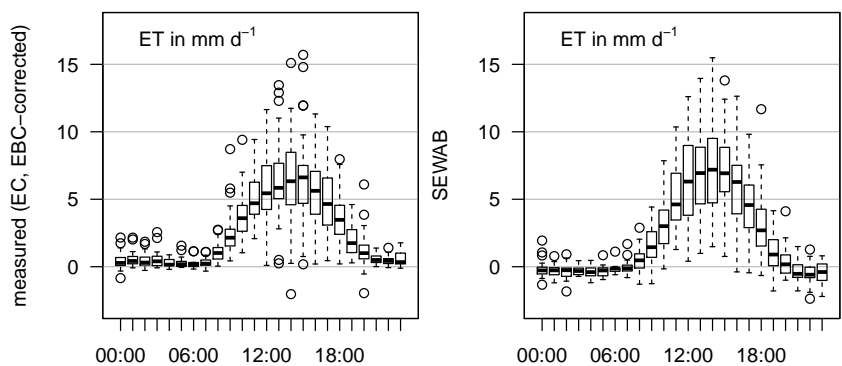

Figure B2. Mean diel course of measured and energy balance corrected evapotranspiration ET (left panel) and SEWAB modelled ET (tile approach according to the EC footprint: $S_{\text {RefEC }}$, right panel) over 61 days during 2010 (3 June to 2 August) at Kema: box plot with median, $25 \%$ and $75 \%$ quartiles; bars represent quartiles \pm 1.5 times interquartile range, dots are outliers. Measured and modelled values are restricted to high flux data quality (flag 1-3). Measured data is corrected according to the surface energy imbalance with the buoyancy flux correction.
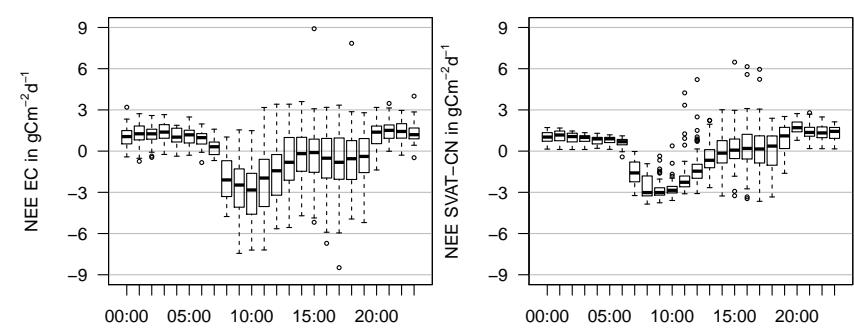

Figure B3. Mean diel course of measured (left panel) and modelled (tile approach according to the EC footprint: $S_{\text {RefEC }}$, right panel) net ecosystem exchange (NEE) over 61 days of 2010 (3 June to 2 August) at Kema: box plot with median, $25 \%$ and $75 \%$ quartiles; bars represent quartiles \pm 1.5 times interquartile range, dots are outliers. Measured and modelled values are restricted to high data quality (flag 1-3 out of a scheme ranging from 1 to 9 , Foken et al., 2004).
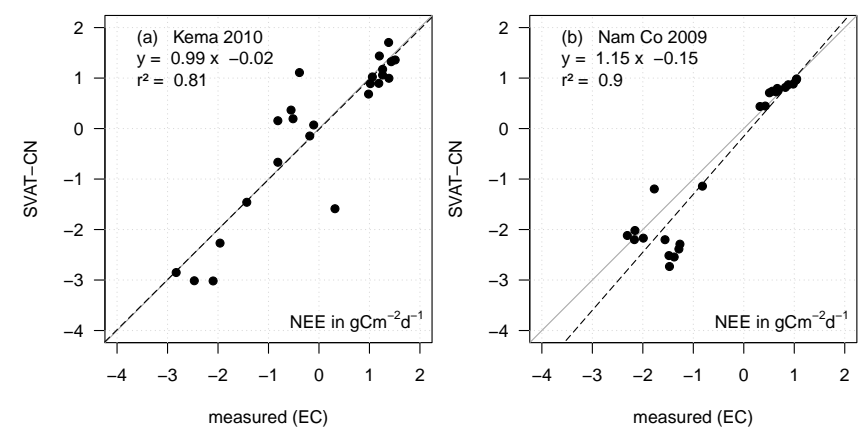

Figure B4. Comparison of hourly medians (see Fig. D3) of measured and modelled net ecosystem exchange for the 2010 campaign at Kema (left panel) and 2009 campaign at Nam Co (right panel). The regression line (dashed, black) is shown as well as the $1: 1$ line (solid, grey).
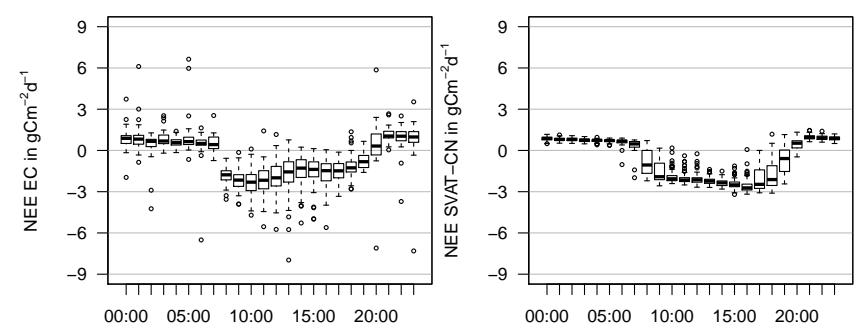

Figure B5. Mean diel course of measured (left panel) and modelled (right panel) net ecosystem exchange (NEE) over 44 days during 2009 (26 June to 8 August) at Nam Co: box plot with median, 25 and $75 \%$ quartiles; bars represent quartiles \pm 1.5 times interquartile range, dots are outliers. Measured and modelled values are restricted to high data quality (flag 1-3 out of a scheme ranging from 1 to 9, Foken et al., 2004). Model parameters for leaf physiology and soil respiration were adapted for best representation of eddy-covariance data (see Sect. 3.2.1). 


\section{The Supplement related to this article is available online at doi:10.5194/bg-11-6633-2014-supplement.}

Acknowledgements. The project was funded within the DFG (German Science Foundation) priority programme 1372 "Tibetan Plateau - Formation - Climate - Ecosystems (TiP)" with the contracts FO 226/18-1,2; GU 406/22-1,2; KU 1184/14-1,2; LE 762/12-1,2; MI 338/7-1,2; WE 2601/4-1,2. Special thanks for the additional funding of the modelling study with the contract AP 34/32-3. The Chinese scientists in the Institute of Tibetan Plateau Research, the Chinese Academy of Sciences were supported by the Chinese National Key Programme for Developing Basic Sciences with the contract 2010CB951701 and the National Natural Science Foundation of China with the contracts 91337212 and 41275010. The research station at Kema was supported by the Volkswagen foundation, in cooperation with the Marburg University and the Tibet University Lhasa, now managed by the Institute of Tibetan Plateau Research, (CAS) as "Naqu Ecological and Environmental Observation and Research Station". All the authors are very grateful to the staff of the research stations at Kema and Nam Co for their support. Furthermore, we thank LI-COR Biosciences for the lending of the chamber system and for their support. This publication is funded by the DFG and the University of Bayreuth in the funding programme Open Access Publishing.

Edited by: P. Stoy

\section{References}

Agam, N., Berliner, P. R., Zangvil, A., and Ben-Dor, E.: Soil water evaporation during the dry season in an arid zone, J. Geophys. Res., 109, D16103, doi:10.1029/2004JD004802, 2004.

Aubinet, M., Vesala, T., and Papale, D.: Eddy Covariance: a Practical Guide to Measurement and Data Analysis, Springer, Dordrecht, Heidelberg, London, New York, 438 pp., 2012.

Avissar, R. and Pielke, R. A.: A parametrization of heterogeneous land surface for atmospheric numerical models and its impact on regional meteorology, Mon. Weather Rev., 117, 2113-2136, 1989.

Ball, J. T., Woodrow, I. E., and Berry, J. A.: A model predicting stomatal conductance and its contribution to the control of photosynthesis under different environmental conditions, in: Progress in Photosynthesis Research, Proceedings of the VII International Photosynthesis Congress, edited by: Binggins, I., 221-224, 1987.

Balsamo, G., Boussetta, S., Dutra, E., Beljaars, A., Viterbo, P., and van den Hurk, B.: Evolution of land surface processes in the IFS, ECMWF Newsletter, 127, 17-22, 2011.

Ben-Gal, A. and Shani, U.: A highly conductive drainage extension to control the lower boundary condition of lysimeters, Plant Soil, 239, 9-17, doi:10.1023/A:1014942024573, 2002.

Biermann, T., Leipold, T., Babel, W., Becker, L., Coners, H., Foken, T., Guggenberger, G., He, S., Ingrisch, J., Kuzyakov, Y., Leuschner, C., Miehe, G., Richards, K., Seeber, E., and Wesche, K.: Tibet Plateau Atmosphere-Ecology-Glaciology Cluster, Joint Kobresia Ecosystem Experiment: Documentation of the first Intensive Observation Period Summer 2010 in Kema, Tibet, Arbeitsergebn., Univ. Bayreuth, Abt. Mikrometeorol., ISSN 1614-8916, 44, 105 pp., http://epub.uni-bayreuth.de/356/, 2011.

Biermann, T., Seeber, E., Schleuß, P., Willinghöfer, S., Leonbacher, J., Schützenmeister, K., Steingräber, L., Babel, W., Coners, H., Foken, T., Guggenberger, G., Kuzyakov, Y., Leuschner, C., Miehe, G., and Wesche, K.: Tibet Plateau Atmosphere-Ecology-Glaciology Cluster Joint Kobresia Ecosystem Experiment: Documentation of the second Intensive Observation Period, Summer 2012 in KEMA, Tibet, Arbeitsergebn., Univ. Bayreuth, Abt. Mikrometeorol., ISSN 1614-8916, 54, 52 pp., http://epub.uni-bayreuth.de/145/, 2013.

Biermann, T., Babel, W., Ma, W., Chen, X., Thiem, E., Ma, Y., and Foken, T.: Turbulent flux observations and modelling over a shallow lake and a wet grassland in the Nam Co basin, Tibetan Plateau, Theor. Appl. Climatol., 116, 301-316, 2014.

Caldwell, M. M., Meister, H. P., Tenhunen, J. D., and Lange, O. L.: Canopy structure, light microclimate and leaf gas exchange of Quercus coccifera L. in a Portugese macchia: measurements in different canopy layers and simulations with a canopy model, Trees, 1, 25-41, 1986.

Charuchittipan, D., Babel, W., Mauder, M., Leps, J.-P., and Foken, T.: Extension of the averaging time of the eddy-covariance measurement and its effect on the energy balance closure Bound.-Lay. Meteorol., 152, 303-327, 2014.

Che, M., Chen, B., Innes, J. L., Wang, G., Dou, X., Zhou, T., Zhang, H., Yan, J., Xu, G., and Zhao, H.: Spatial and temporal variations in the end date of the vegetation growing season throughout the Qinghai-Tibetan Plateau from 1982 to 2011, Agr. Forest Meteorol., 189/190, 81-90, 2014.

Chen, Y., Yang, K., Tang, W., Qin, J., and Zhao, L.: Parameterizing soil organic carbon's impacts on soil porosity and thermal parameters for Eastern Tibet grasslands, Sci. China Ser. D, 55, 1001-1011, 2012.

Clapp, R. B. and Hornberger, G. M.: Empirical equations for some soil hydraulic properties, Water Resour. Res., 14, 601-604, 1978.

Cui, X. F. and Graf, H.-F.: Recent land cover changes on the Tibetan Plateau: a review, Clim. Change, 94, 47-61, 2009.

Cui, X. F., Graf, H.-F., Langmann, B., Chen, W., and Huang, R.H.: Climate impacts of anthropogenic land use changes on the Tibetan Plateau, Global Planet. Change, 54, 33-56, doi:10.1016/j.gloplacha.2005.07.006, 2006.

Cui, X. F., Graf, H.-F., Langmann, B., Chen, W., and Huang, R.-H.: Hydrological impacts of deforestation at the Southeast Tibetan Plateau, Earth Interact., 11, 1-18, 2007a.

Cui, X. F., Langmann, B., and Graf, H.-F.: Summer Monsoonal Rainfall Simulation on the Tibetan Plateau with a Regional Climate Model Using a One-way Double-nesting System, SOLA, 3, 49-52, 2007b.

Evans, R. A. and Love, R. M.: The step-point method of sampling - a practical tool in range research, J. Range Manage., 10, 208-212, 1957.

Falge, E.: Die Modellierung der Kronendachtranspiration von Fichtenbeständen (Picea abies (L.) Karst., Bayreuther Forum Ökologie, 48, 215 pp., 1997.

Falge, E., Tenhunen, J., Aubinet, M., Bernhofer, C., Clement, R., Granier, A., Kowalski, A., Moors, E., Pilegaard, K., Rannik, Ü., and Rebmann, C.: A model-based study of carbon fluxes at ten 
European forest sites, in: Fluxes of Carbon, Water and Energy of European Forests, Ecological Studies Series 163, edited by: Valentini, R., Springer, Berlin, Heidelberg, 151-177, 2003.

Falge, E., Reth, S., Brüggemann, N., Butterbach-Bahl, K., Goldberg, V., Oltchev, A., Schaaf, S., Spindler, G., Stiller, B., Queck, R., Köstner, B., and Bernhofer, C.: Comparison of surface energy exchange models with eddy flux data in forest and grassland ecosystems of Germany, Ecol. Model., 188, 174-216, 2005.

Farquhar, G. D., von Caemmerer, S., and Berry, J. A.: A biochemical of photosynthetic $\mathrm{CO}_{2}$ assimilation in leaves of $\mathrm{C}_{3}$ species, Planta, 149, 78-90, 1980.

Foken, T.: The energy balance closure problem - an overview, Ecol. Appl., 18, 1351-1367, 2008.

Foken, T. and Wichura, B.: Tools for quality assessment of surfacebased flux measurements, Agr. Forest Meteorol., 78, 83-105, 1996.

Foken, T., Göckede, M., Mauder, M., Mahrt, L., Amiro, B. D., and Munger, J. W.: Post-field data quality control, in: Handbook of Micrometeorology: a Guide for Surface Flux Measurement and Analysis, edited by: Lee, X., Massman, W. J., and Law, B., Kluwer, Dordrecht, 181-208, 2004.

Foken, T., Aubinet, M., Finnigan, J., Leclerc, M. Y., Mauder, M., and Paw U, K. T.: Results of a panel discussion about the energy balance closure correction for trace gases, B. Am. Meteorol. Soc., 92, ES13-ES18, 2011.

Foken, T., Leuning, R., Oncley, S. P., Mauder, M., and Aubinet, M.: Corrections and data quality in: Eddy Covariance: a Practical Guide to Measurement and Data Analysis, edited by: Aubinet, M., Vesala, T., and Papale, D., Springer, Dordrecht, Heidelberg, London, New York, 85-131, 2012a.

Foken, T., Meixner, F. X., Falge, E., Zetzsch, C., Serafimovich, A., Bargsten, A., Behrendt, T., Biermann, T., Breuninger, C., Dix, S., Gerken, T., Hunner, M., Lehmann-Pape, L., Hens, K., Jocher, G., Kesselmeier, J., Lüers, J., Mayer, J.-C., Moravek, A., Plake, D., Riederer, M., Rütz, F., Scheibe, M., Siebicke, L., Sörgel, M., Staudt, K., Trebs, I., Tsokankunku, A., Welling, M., Wolff, V., and Zhu, Z.: Coupling processes and exchange of energy and reactive and non-reactive trace gases at a forest site - results of the EGER experiment, Atmos. Chem. Phys., 12, 1923-1950, doi:10.5194/acp-12-1923-2012, 2012 b.

Fratini, G. and Mauder, M.: Towards a consistent eddy-covariance processing: an intercomparison of EddyPro and TK3, Atmos. Meas. Tech., 7, 2273-2281, doi:10.5194/amt-7-2273-2014, 2014.

Friend, A. D. and Kiang, N. Y.: Land surface model development for the GISS GCM: effects of improved canopy physiology on simulated climate, J. Climate, 18, 2883-2902, 2005.

Friend, A. D., Stevens, A. K., Knox, R. G., and Cannell, M. G. R.: A process-based, terrestrial biosphere model of ecosystem dynamics (Hybrid v3.0), Ecol. Model., 95, 249-287, 1997.

Gee, G. W., Newman, B. D., Green, S. R., Meissner, R., Rupp, H., Zhang, Z. F., Keller, J. M., Waugh, W. J., van der Velde, M., and Salazar, J.: Passive wick fluxmeters: design considerations and field applications, Water Resour. Res., 45, W04420, doi:10.1029/2008WR007088, 2009.

Gerken, T., Babel, W., Hoffmann, A., Biermann, T., Herzog, M., Friend, A. D., Li, M., Ma, Y., Foken, T., and Graf, H.-F.: Turbulent flux modelling with a simple 2-layer soil model and ex- trapolated surface temperature applied at Nam Co Lake basin on the Tibetan Plateau, Hydrol. Earth Syst. Sci., 16, 1095-1110, doi:10.5194/hess-16-1095-2012, 2012.

Gerken, T., Babel, W., Sun, F., Herzog, M., Ma, Y., Foken, T., and Graf, H.-F.: Uncertainty in atmospheric profiles and its impact on modeled convection development at Nam Co Lake, Tibetan Plateau, J. Geophys. Res.-Atmos., 118, 12317-12331, doi:10.1002/2013JD020647, 2013.

Gerken, T., Biermann, T., Babel, W., Herzog, M., Ma, Y., Foken, T., and Graf, H.-F.: A modelling investigation into lake-breeze development and convection triggering in the Nam Co Lake basin, Tibetan Plateau, Theor. Appl. Climatol., 117, 149-167, 2014.

Göckede, M., Rebmann, C., and Foken, T.: A combination of quality assessment tools for eddy covariance measurements with footprint modelling for the characterisation of complex sites, Agr. Forest Meteorol., 127, 175-188, 2004.

Göckede, M., Markkanen, T., Hasager, C. B., and Foken, T.: Update of a footprint-based approach for the characterisation of complex measuring sites, Bound.-Lay. Meteorol., 118, 635-655, 2006.

Hafner, S., Unteregelsbacher, S., Seeber, E., Lena, B., Xu, X., Li, X., Guggenberger, G., Miehe, G., and Kuzyakov, Y.: Effect of grazing on carbon stocks and assimilate partitioning in a Tibetan montane pasture revealed by ${ }^{13} \mathrm{CO}_{2}$ pulse labeling, Glob. Change Biol., 18, 528-538, 2012.

Harris, R. B.: Rangeland degradation on the Qinghai-Tibetan plateau: A review of the evidence of its magnitude and causes, J. Arid Environ., 74, 1-12, 2010.

Herzog, M., Oberhuber, J. M., and Graf, H. F.: A prognostic turbulence scheme for the nonhydrostatic plume model ATHAM, J. Atmos. Sci., 60, 2783-2796, 2003.

Hillel, D.: Applications of Soil Physics, Academic Press, New York, 385 pp., 1980.

Holzner, W. and Kriechbaum, M.: Pastures in South and Central Tibet (China), I. Methods for a rapid assessment ofpasture conditions, Bodenkultur, 51, 259-266, 2000.

Hong, J., Kim, J., Ishikawa, H., and Ma, Y.: Surface layer similarity in the nocturnal boundary layer: the application of Hilbert-Huang transform, Biogeosciences, 7, 1271-1278, doi:10.5194/bg-7-1271-2010, 2010.

Hu, J., Hopping, K. A., Bump, J. K., Kang, S., and Klein, J. A.: Climate change and water use partitioning by different plant functional groups in a grassland on the Tibetan Plateau, PLOS ONE, 8, e75503, doi:10.1371/journal.pone.0075503, 2013.

Ingrisch, J., Biermann, T., Seeber, E., Leipold, T., Li, M., Ma, Y., Xu, X., Miehe, G., Guggenberger, G., Foken, T., and Kuzyakov, Y.: Carbon pools and fluxes in a Tibetan alpine Kobresia pygmaea pasture partitioned by coupled eddy-covariance measurements and ${ }^{13} \mathrm{CO}_{2}$ pulse labeling, Sci. Total Environ., in print, 2014.

Ingwersen, J., Steffens, K., Högy, P., Warrach-Sagi, K., Zhunusbayeva, D., Poltoradnev, M., Gäbler, R., Wizemann, H.-D., Fangmeier, A., Wulfmeyer, V., and Streck, T.: Comparison of Noah simulations with eddy covariance and soil water measurements at a winter wheat stand, Agr. Forest Meteorol., 151, 345-355, 2011.

IUSS-ISRIC-FAO: World Reference Base for Soil Resources: a Framework for International Classification, Correlation and Communication, 2nd edn., World soil resources reports, 103, 
Food and Agriculture Organization of the United Nations, Rome, 128 pp., 2006.

Kaiser, K., Miehe, G., Barthelmes, A., Ehrmann, O., Scharf, A., Schult, M., Schlütz, F., Adamczyk, S., and Frenzel, B.: Turfbearing topsoils on the central Tibetan Plateau, China: pedology, botany, geochronology, Catena, 73, 300-311, 2008.

Kracher, D., Mengelkamp, H.-T., and Foken, T.: The residual of the energy balance closure and its influence on the results of three SVAT models, Meteorol. Z., 18, 647-661, 2009.

Kuzyakov, Y. and Domanski, G.: Carbon input by plants into the soil, review, J. Plant Nutr. Soil Sc., 163, 421-431, 2000.

Liu, W., Wang, X., Zhou, L., and Zhou, H.: Studies on destruction, prevention and control of Plateau Pikas in Kobresia pygmaea meadow, Acta Theriol. Sin., 23, 214-219, 2003 (in Chinese with English abstract).

Lloyd, J. and Taylor, J. A.: On the temperature dependence of soil respiration, Funct. Ecol., 8, 315-323, 1994.

Louis, J. F.: A parametric model of vertical fluxes in the atmosphere, Bound.-Lay. Meteorol., 17, 187-202, 1979.

Lundegardh, H.: Ecological studies in the assimilation of certain forest plants and shore plants, Svensk Botaniska Tidskrift, 15, 46-94, 1921.

Ma, Y., Tsukamoto, O., Wang, J., Ishikawa, H., and Tamagawa, I.: Analysis of aerodynamic and thermodynamic parameters on the grassy marshland surface of Tibetan Plateau, Prog. Nat. Sci., 12, 36-40, 2002.

Ma, Y., Kang, S., Zhu, L., Xu, B., Tian, L., and Yao, T.: Roof of the world: Tibetan observation and research platform, B. Am. Meteorol. Soc., 89, 1487-1492, 2008.

Ma, Y., Zhong, L., Wang, B., Ma, W., Chen, X., and Li, M.: Determination of land surface heat fluxes over heterogeneous landscape of the Tibetan Plateau by using the MODIS and in situ data, Atmos. Chem. Phys., 11, 10461-10469, 2011, http://www.atmos-chem-phys.net/11/10461/2011/.

Ma, Y., Han, C., Zhong, L., Wang, B., Zhu, Z., Wang, Y., Zhang, L., Meng, C., Xu, C., and Amatya, P.: Using MODIS and AVHRR data to determine regional surface heating field and heat flux distributions over the heterogeneous landscape of the Tibetan Plateau, Theor. Appl. Climatol., 117, 643-652, 2014.

Mauder, M. and Foken, T.: Documentation and Instruction Manual of the Eddy Covariance Software Package TK2, Arbeitsergebn., Univ. Bayreuth, Abt. Mikrometeorol., 26, 42 pp., http: //epub.uni-bayreuth.de/884/, 2004.

Mauder, M. and Foken, T.: Documentation and Instruction Manual of the Eddy Covariance Software Package TK3, Arbeitsergebn., Univ. Bayreuth, Abt. Mikrometeorol., 46, 58 pp., http: //epub.uni-bayreuth.de/342/, 2011.

Mauder, M., Foken, T., Clement, R., Elbers, J. A., Eugster, W., Grünwald, T., Heusinkveld, B., and Kolle, O.: Quality control of CarboEurope flux data - Part 2: Inter-comparison of eddy-covariance software, Biogeosciences, 5, 451-462, doi:10.5194/bg-5-451-2008, 2008.

Maussion, F., Scherer, D., Mölg, T., Collier, E., Curio, J., and Finkelnburg, R.: Precipitation Seasonality and Variability over the Tibetan Plateau as Resolved by the High Asia Reanalysis, J. Climate, 27, 1910-1927, 2014.

Mengelkamp, H.-T., Warrach, K., and Raschke, E.: SEWAB a parameterization of the surface energy and water balance for atmo- spheric and hydrologic models, Adv. Water Res., 23, 165-175, 1999.

Mengelkamp, H. T., Kiely, G., and Warrach, K.: Evaluation of the hydrological components added to an atmospheric land-surface scheme, Theor. Appl. Climatol., 69, 199-212, 2001.

Miehe, G., Kaiser, K., Co, S., and Liu, J.: Geo-ecological transect studies in northeast Tibet (Qinghai, China) reveal human-made mid- Holocene environmental changes in the upper Yellow River catchment changing forest to grassland, Erdkunde, 62, 187-199, 2008a.

Miehe, G., Miehe, S., Kaiser, K., Liu, J. Q., and Zhao, X. Q.: Status and dynamics of Kobresia pygmaea ecosystem on the Tibetan plateau, Ambio, 37, 272-279, 2008b.

Miehe, G., Miehe, S., Bach, K., Nölling, J., Hanspach, J., Reudenbach, C., Kaiser, K., Wesche, K., Mosbrugger, V., Yang, Y. P., and Ma, Y. M.: Plant communities of central Tibetan pastures in the Alpine Steppe/Kobresia pygmaea ecotone, J. Arid Environ., 75, 711-723, 2011.

Miehe, G., Miehe, S., Böhner, J., Kaiser, K., Hensen, I., Madsen, D., Liu, J., and Opgenoorth, L.: How old is the human footprint in the world's largest alpine ecosystem? A review of multiproxy records from the Tibetan Plateau from the ecologists' viewpoint, Quaternary Sci. Rev., 86, 190-209, 2014.

Mihailovic, D. T., Pielke, R. A., Rajkovic, B., Lee, T. J., and Jeftic, M.: A resistance representation of schemes for evaporation from bare and partly plant-covered surfaces for use in atmospheric models, J. Appl. Meteorol., 32, 1038-1054, 1993.

Mölders, N.: Land-Use and Land-Cover Changes, Impact on Climate and Air Quality, Springer, Dordrecht, Heidelberg, London, New York, 189 pp., 2012.

Moldrup, P., Rolston, D. E., and Hansen, A. A.: Rapid and numerically stable simulation of one dimensional, transient water flow in unsaturated, layered soils, Soil Sci., 148, 219-226, 1989.

Moldrup, P., Rolston, D. E., Hansen, A. A., and Yamaguchi, T.: A simple, mechanistic model for soil resistance to plant water uptake, Soil Sci., 151, 87-93, 1991.

Mügler, I., Gleixner, G., Günther, F., Mäusbacher, R., Daut, G., Schütt, B., Berking, J., Schwalb, A., Schwark, L., Xu, B., Yao, T., Zhu, L., and Yi, C.: A multi-proxy approach to reconstruct hydrological changes and Holocene climate development of Nam Co, Central Tibet, J. Paleolimnol., 43, 625-648, 2010.

Niu, Y.: The study of environment in the Plateau of Qin-Tibet, Progr. Geogra., 18, 163-171, 1999 (in Chinese with English abstract).

Noilhan, J. and Planton, S.: A Simple parameterization of land surface processes for meteorological models, Mon. Weather Rev., 117, 536-549, 1989.

Oberhuber, J. M., Herzog, M., Graf, H. F., and Schwanke, K.: Volcanic plume simulation on large scales, J. Volcanol. Geoth. Res., 87, 29-53, 1998.

Rebmann, C., Kolle, O., Heinesch, B., Queck, R., Ibrom, A., and Aubinet, M.: Data acquisition and flux calculations, in: Eddy Covariance: A Practical Guide to Measurement and Data Analysis, edited by: Aubinet, M., Vesala, T., and Papale, D., Springer, Dordrecht, Heidelberg, London, New York, 59-83, 2012.

Reichstein, M.: Drought Effects on Ecosystem Carbon Anwater Exchange in Three Mediterranean Forest Ecosytems - a Combined Top-Down and Bottom-Up Analysis, Bayreuther Forum Ökologie, 89, 1-150, 2001. 
Reth, S., Göckede, M., and Falge, E.: $\mathrm{CO}_{2}$ efflux from agricultural soils in Eastern Germany - comparison of a closed chamber system with eddy covariance measurements, Theor. Appl. Climatol., 80, 105-120, 2005a.

Reth, S., Hentschel, K., Drösler, M., and Falge, E.: DenNit - experimental analysis and modelling of soil $\mathrm{N}_{2} \mathrm{O}$ efflux in response on changes of soil water content, soil temperature, soil $\mathrm{pH}$, nutrient availability and the time after rain event, Plant Soil, 272, 349-363, 2005b.

Reth, S., Reichstein, M., and Falge, E.: The effect of soil water content, soil temperature, soil $\mathrm{pH}$-value and the root mass on soil $\mathrm{CO}_{2}$ efflux - a modified model, Plant Soil, 268, 21-33, 2005c.

Richards, L. A.: Capillary conductivity of liquids in porous mediums, Physics, 1, 318-333, 1931.

Riederer, M.: Carbon fluxes of an extensive meadow and attempts for flux partitioning, Ph.D. thesis, University of Bayreuth, 167 pp., 2014.

Riederer, M., Serafimovich, A., and Foken, T.: Net ecosystem $\mathrm{CO}_{2}$ exchange measurements by the closed chamber method and the eddy covariance technique and their dependence on atmospheric conditions, Atmos. Meas. Tech., 7, 1057-1064, doi:10.5194/amt7-1057-2014, 2014.

Shen, M., Zhang, G., Cong, N., Wang, S., Kong, W., and Piao, S.: Increasing altitudinal gradient of spring vegetation phenology during the last decade on the Qinghai-Tibetan Plateau, Agr. Forest Meteorol., 189-190, 71-80, 2014.

Shi, Q., and Liang, S.: Surface-sensible and latent heat fluxes over the Tibetan Plateau from ground measurements, reanalysis, and satellite data, Atmos. Chem. Phys., 14, 5659-5677, doi:10.5194/acp-14-5659-2014, 2014.

Singh, J. and Gupta, S.: Plant decomposition and soil respiration in terrestrial ecosystems, Bot. Rev., 43, 449-528, 1977.

Staudt, K., Serafimovich, A., Siebicke, L., Pyles, R. D., and Falge, E.: Vertical structure of evapotranspiration at a forest site (a case study), Agr. Forest Meteorol., 151, 709-729, 2011.

Swinnen, J., Vanveen, J. A., and Merckx, R.: C-14 Pulse labeling of field-grown spring whean - an evaluation of its use in rhizosphere carbon budget estimations, Soil Biol. Biochem., 26, 161-170, 1994.

Tanaka, K., Ishikawa, H., Hayashi, T., Tamagawa, I., and Ma, Y.: Surface energy budget at Amdo on the Tibetan Plateau using GAME/Tibet IOP98 data, J. Meteorol. Soc. Jpn., 79, 505-517, 2001.

Tenhunen, J. D., Siegwolf, R. A., and Oberbauer, S. F.: Effects of phenology, physiology, and gradients in community composition, structure, and microclimate on tundra ecosystem $\mathrm{CO}_{2}$ exchange., in: Ecophysiology of Photosynthesis, edited by: Schulze, E.-D. and Caldwell, M. M., Springer, Berlin, Heidelberg, New York, 431-460, 1995.

Unteregelsbacher, S., Hafner, S., Guggenberger, G., Miehe, G., Xu, X., Liu, J., and Kuzyakov, Y.: Response of long-, mediumand short-term processes of the carbon budget to overgrazinginduced crusts in the Tibetan Plateau, Biogeochemistry, 111, 187-201, 2012.

van den Bergh, T., Inauen, N., Hiltbrunner, E., and Körner, C.: Climate and plant cover co-determine the elevational reduction in evapotranspiration in the Swiss Alps, J. Hydrol., 500, 75-83, 2013. van Genuchten, M. T.: A closed-form equation for predicting the hydraulic conductivity of unsaturated soils, Soil Sci. Soc. Am. J., 44, 892-898, 1980.

Wei, D., Ri, X., Wang, Y., Wang, Y., Liu, Y., and Yao, T.: Responses of $\mathrm{CO}_{2}, \mathrm{CH}_{4}$ and $\mathrm{N}_{2} \mathrm{O}$ fluxes to livestock exclosure in an alpine steppe on the Tibetan Plateau, China, Plant Soil, 359, 45-55, doi:10.1007/s11104-011-1105-3, 2012.

Wieser, G., Hammerle, A., and Wohlfahrt, G.: The water balance of grassland ecosystems in the Austrian Alps, Arct. Antarct. Alp. Res., 40, 439-445, 2008.

Wohlfahrt, G., Bahn, M., Horak, I., Tappeiner, U., and Cernusca, A.: A nitrogen sensitive model of leaf carbon dioxide and water vapour gas exchange: application to 13 key species from differently managed mountain grassland ecosystems, Ecol. Model., 113, 179-199, 1998.

Yao, T., Thompson, L. G., Mosbrugger, V., Zhang, F., Ma, Y., Luo, T., Xu, B., Yang, X., Joswiak, D. R., Wang, W., Joswiak, M. E., Devkota, L. P., Tayal, S., Jilani, R., and Fayziev, R.: Third Pole Environment (TPE), Environ. Dev., 3, 52-64, 2012.

Yang, K., Koike, T., and Yang, D.: Surface flux parameterization in the Tibetan Plateau, Bound.-Lay. Meteorol., 116, 245-262, 2003.

Yang, K., Koike, T., Fuji, H., Tamura, T., Xu, X., Bian, L., and Zhou, M.: The daytime evolution of the atmospheric boundary layer and convection over the Tibetan Plateau: observations and simulations, J. Meteorol. Soc. Jpn., 82, 1777-1792, 2004.

Yang, K., Koike, T., Ye, B., and Bastidas, L.: Inverse analysis of the role of soil vertical heterogeneity in controlling surface soil state and energy partition, J. Geophys. Res., 110, D08101, doi:10.1029/2004JD005500, 2005.

Yang, K., Koike, T., Ishikawa, H., Kim, J., Li, X., Liu, H., Liu, S., Ma, Y., and Wang, J.: Turbulent flux transfer over bare-soil surfaces: characteristics and parameterization, J. Appl. Meteorol. Clim., 47, 276-290, 2008.

Yang, K., Chen, Y.-Y., and Qin, J.: Some practical notes on the land surface modeling in the Tibetan Plateau, Hydrol. Earth Syst. Sci., 13, 687-701, doi:10.5194/hess-13-687-2009, 2009.

Yang, K., Ye, B., Zhou, D., Wu, B., Foken, T., Qin, J., and Zhou, Z.: Response of hydrological cycle to recent climate changes in the Tibetan Plateau, Clim. Change, 109, 517-534, 2011.

Yang, K., Qin, J., Zhao, L., Chen, Y., Tang, W., Lazhu, M. H., Chen, Z., Lv, N., Ding, B., Wu, H., and Lin, C.: A Multiscale Soil Moisture and Freeze-Thaw Monitoring Network on the Third Pole, B. Am. Meteorol. Soc., 94, 1907-1916, 2013.

Yang, K., Wu, H., Qin, J., Lin, C., Tang, W., and Chen, Y.: Recent climate changes over the Tibetan Plateau and their impacts on energy and water cycle: A review, Global Planet. Change, 112, 79-91, 2014.

Zhang, D., Xu, W., Li, J., Cai, Z., and An, D.: Frost-free season lengthening and its potential cause in the Tibetan Plateau from 1960 to 2010, Theor. Appl. Climatol., 115, 441-450, 2014.

Zhou, D., Eigenmann, R., Babel, W., Foken, T., and Ma, Y.: Study of near-ground free convection conditions at Nam Co station on the Tibetan Plateau, Theor. Appl. Climatol., 105, 217-228, 2011.

Zhou, H., Zhao, X., Tang, Y., Gu, S., and Zhou, L.: Alpine grassland degradation and its control in the source region of the Yangtze and Yellow Rivers, China, Grassland Sci., 51, 191-203, 2005. 